\title{
The Activation Energy of the Skeletal Isomerization in the Radical Cations of Toluene and Cycloheptatriene by Mass Spectrometry of their 2-Phenylethyl Derivatives
}

\author{
Dietmar Kuck $\dagger$ and Hans-Fr. Grützmacher \\ Fakultät für Chemie der Universität Bielefeld, Universitätsstrasse, D-4800 Bielefeld 1, Germany
}

\begin{abstract}
The unimolecnlar mass spectrometric fragmentations of the molecular ions of 1,3-diphenylpropane, 1-(7cycloheptatrienyl)-2-phenylethane and the 1-phenyl-2-tolylethanes and their [ $d_{5}$ ]phenyl analogues have been investigated by metastable ion techniques and measurements of ionization and appearance energies. By comparing the formation of $\left[\mathrm{C}_{7} \mathrm{H}_{7}\right]^{+},\left[\mathrm{C}_{7} \mathrm{H}_{8}\right]^{+},\left[\mathrm{C}_{8} \mathrm{H}_{8}\right]^{+}$and $\left[\mathrm{C}_{8} \mathrm{H}_{9}\right]^{+}$it is shown that the molecular ions of the four diaryl isomers do not undergo ring expansion reactions of the aromatic nuclei prior to these fragmentations. Conversely, the molecular ions of the cycloheptatrienyl isomer suffer in part a contraction of the 7-membered ring. From these results and from the measured ionization and appearance energies lower limits to the activation energies of these skeletal isomerizations have been estimated yielding $E_{\mathrm{isom}}^{ \pm}>33 \pm 5 \mathrm{kcal} \mathrm{mol}^{-1}$ formonoalkylbenzene, $E_{\mathrm{isom}}^{\neq}>202 \pm 5 \mathrm{kc} \mathrm{mol}^{-1}$ for 7 -alkylcycloheptatriene and $E_{\text {isom }}^{*}>40 \pm 5 \mathrm{kcal} \mathrm{mol}^{-1}$ for dialkylbenzene positive radical ions. Upper limits can be deduced from literature evidence yielding $E_{\mathrm{isom}}^{\neq}<45 \mathrm{kcal} \mathrm{mol}^{-1}$ for monoalkylbenzene and $E_{\mathrm{isom}}^{\neq}<53 \mathrm{kcal}_{4 \mathrm{~mol}}^{-1}$ for dialkylbenzene positive radical ions. The activation energy thus estimated for monoalkylbenzene is in excellent agreement with the recently calculated value(s) for the toluene ion.
\end{abstract}

\section{INTRODUCTION}

The well known rearrangement reactions in isolated ('gaseous') $\left[\mathrm{C}_{7} \mathrm{H}_{7}\right]^{+}$fragment ions formed from toluene, cycloheptatriene and many of their derivatives in the mass spectrometer are often preceded by skeletal rearrangements in the corresponding molecular ions themselves. Since the classical work of Meyerson and his co-workers ${ }^{1}$ both sets of rearrangements (which will be distinguished in the following by the terms $\left[\mathrm{C}_{7} \mathrm{H}_{7}\right]^{+}$-type' and ' $\left[\mathrm{C}_{7} \mathrm{H}_{8}\right]^{+*}$-type isomerizations') were investigated thoroughly using different mass spectrometric methods, and the results have been reviewed several times. ${ }^{2-5}$

As far as the $\left[\mathrm{C}_{7} \mathrm{H}_{8}\right]^{+\cdot}$-type rearrangement reactions in toluene, cycloheptatriene and related molecular ions are concerned there are several competitive isomerization pathways. For example, Baldwin, McLafferty and Jerina observed at least four different (hydrogen and skeletal) rearrangement mechanisms in variously labelled toluene molecular ions. ${ }^{6}$ However, it is obvious for all $\left[\mathrm{C}_{7} \mathrm{H}_{8}\right]^{+*}$ (and $\left[\mathrm{C}_{7} \mathrm{H}_{7}\right]^{+}$)-type isomerizations that they can be observed only by means of succeeding fragmentation reactions, which in general require rather high internal energies. For example, the above mentioned rearrangements must take place in toluene radical cations excited by at least c. 5.0.7 and even $12.2 \mathrm{eV}^{6}$ (c. 115 and $280 \mathrm{kcal} \mathrm{mol}^{-1}$ ) for them to be able to expel $\mathrm{CH}_{3}$ and ' $\mathrm{CH}_{6}$ ' fragments. It is noteworthy that upon electron impact, even loss of $\mathrm{H}^{\circ}$

$\uparrow$ Author to whom correspondence should be addressed. from toluene and cycloheptatriene requires a minimum energy of 2.9 and $1.7 \mathrm{eV}^{7 \mathrm{~b}}(67$ and 39 $\mathrm{kcal} \mathrm{mol}^{-1}$ ), respectivly. This appears to be sufficient to produce interconverting $\left[\mathrm{C}_{7} \mathrm{H}_{8}\right]^{+\cdot}$ molecular ions. Thus, the experimental investigation of the activation barrier for e.g. $\left[\mathrm{C}_{7} \mathrm{H}_{8}\right]^{+-}$-type isomerizations by succeeding fragmentations is limited principally to an estimation of a maximum value which can be derived approximately from the activation barrier or appearance energy of the most favourable fragmentation pathway.

However, there exists a second experimental approach which has not been used thoroughly until now. If the parent molecular ion (e.g. $\left[\mathrm{C}_{7} \mathrm{H}_{8}\right]^{+*}$ from toluene and cycloheptatriene) is enlarged suitably to allow an additional fragmentation (or isomerization) pathway of a particularly low activation energy, the otherwise observed isomerizations of the molecular ions can no longer occur. In this case a minimum value for the isomerization processes can be estimated if the energy requirement of the additional reaction channel is known. An application of the latter approach has become of particular interest because the energy profiles of isomerization reactions of ions, some of which have been determined recently, ${ }^{8}$ can be investigated also by theoretical methods. ${ }^{9,10}$ Dewar and Landman ${ }^{\text {toc }}$ calculated the isomerization and fragmentation pathways of toluene and cycloheptatriene molecular ions by means of the semi-empirical MINDO/3 method. Therefore, in the case of the $\left[\mathrm{C}_{7} \mathrm{H}_{8}\right]^{+*}$-type isomerization, the results of the experimental and theoretical approaches can be compared. 
Table 1. Deuterium contents of the labelled compounds (\%)<smiles>[R9]c1ccc(CCCc2ccc(CCCc3ccccc3)cc2)cc1</smiles>
1/1a 2/2a<smiles>Cc1cccc(CCc2cccc(P)c2)c1</smiles><smiles>Cc1ccc(CCc2ccc(P)cc2)cc1</smiles>

$\mathbf{5} / \mathbf{5 a}$

\begin{tabular}{cccccc}
\hline$x=0$ & $x=5$ & $d_{5}$ & $d_{4}$ & $d_{3}$ & $d_{2}$ \\
1 & $1 a$ & 81.0 & 14.1 & 4.1 & 0.8 \\
2 & $2 a$ & 95.8 & 3.7 & 0.5 & - \\
3 & $3 a$ & 93.5 & 5.5 & 1.0 & - \\
4 & $4 a$ & 91.9 & 6.7 & 1.4 & - \\
5 & $5 a$ & 90.1 & 6.3 & 2.8 & 0.8 \\
\hline
\end{tabular}

One example for the conservation of a toluene-like structure before fragmentation is represented by the molecular ions of 1,3-diphenylpropane (1). ${ }^{11}$ The six hydrogens in the meta and para positions of the phenyl rings are not involved in the $H$ transfer steps, ${ }^{11 \mathrm{~b}}$ and thus the $\left[\mathrm{C}_{7} \mathrm{H}_{8}\right]^{+\cdot}$-type isomerizations known from other arylaliphatic hydrocarbon radical cations appear to be suppressed by the energetically more favourable isomerization and fragmentation pathways. ${ }^{11 \mathrm{a}, 11 \mathrm{~b}}$

In order to study this effect in more detail, four isomers of 1, 1-(7-cycloheptatrienyl)-2-phenylethane (2) and the three 1-phenyl-2-tolylethanes (3, 4 and 5) and their phenyl- $d_{5}$ analogues $(\mathbf{2 a}-\mathbf{5 a})$, have been synthesized (Table 1). The mass spectral fragmentations of these five $\left[\mathrm{C}_{15} \mathrm{H}_{16}\right]^{+*}$ isomers differ significantly, especially at very low internal energies allowing an experimental estimation of a lower limit to the activation energy for the $\left[\mathrm{C}_{7} \mathrm{H}_{8}\right]^{+\cdot}$-type isomerization.

\section{RESULTS}

\section{Fragmentations of unstable and of metastable molecu- lar ions}

Table 2 shows the relative abundances of fragment ions containing 7 and 8 carbons (herein after referred to as the $C_{7}$ and $C_{8}$ fragment ions), $m / z \quad 89-92$ and $\mathrm{m} / z$ 102-106, respectively formed within the ion
Table 2. Relative abundances of the $C_{7}$ and $C_{8}$ fragment ions ${ }^{2}$ formed from the isomers $\mathrm{R}-\mathrm{CH}_{2} \mathrm{CH}_{2} \mathrm{C}_{6} \mathrm{H}_{5}$ (1-5) and $\mathrm{R}-\mathrm{CH}_{2} \mathrm{CH}_{2} \mathrm{C}_{6} \mathrm{D}_{5}$ (1a-5a) within the ion source with $70 \mathrm{eV}$ electrons and relative abundances of the (unlabelled) molecular ions ${ }^{\mathrm{b}}$

\begin{tabular}{|c|c|c|c|c|c|c|c|c|c|c|}
\hline$m / 2$ & $\mathrm{R}=\mathrm{C}_{1}^{\prime}$ & $\begin{array}{c}\mathrm{H}_{5} \mathrm{CH}_{2} \\
\text { (a }\end{array}$ & $\begin{array}{c}R=17-c . c \\
2\end{array}$ & $\begin{array}{c}\left.-\mathrm{C}_{2} \mathrm{H}_{7}\right) \\
2 \mathrm{as}\end{array}$ & $\begin{array}{c}R=0-C \\
3\end{array}$ & $\underset{\mathbf{3 a}}{\mathrm{H}_{3} \mathrm{C}_{6} \mathrm{H}_{4}}$ & $\begin{array}{c}R=m \cdot c \\
4\end{array}$ & $\underset{\mathbf{4 a}}{\mathrm{CH}_{3} \mathrm{C}_{6} \mathrm{H}_{4}}$ & $\begin{array}{c}R=p-C \\
5\end{array}$ & $\begin{array}{c}\mathrm{H}_{3} \mathrm{C}_{\mathrm{a}} \mathrm{H}_{4} \\
\mathbf{5 a}\end{array}$ \\
\hline 89 & 0.8 & 0.5 & 1.8 & 1.3 & 2.2 & 0.6 & 2.0 & 0.9 & 2.1 & 0.7 \\
\hline 90 & 0.3 & 0.3 & 0.5 & 0.5 & 0.4 & 0.3 & 0.4 & 0.3 & 0.4 & 0.3 \\
\hline 91 & 26.3 & 12.5 & 54.0 & 31.0 & 17.5 & 1.4 & 25.1 & 4.0 & 12.5 & 4.0 \\
\hline 92 & 45.0 & 19.8 & 8.0 & 2.4 & 0.3 & 0.4 & 0.5 & 0.6 & 0.4 & 0.5 \\
\hline 93 & - & 5.1 & - & 1.0 & - & 0.4 & - & 2.1 & - & 2.0 \\
\hline 94 & - & 0.3 & - & 0.5 & - & 0.2 & - & 0.3 & - & 0.3 \\
\hline 95 & - & 4.0 & - & 3.0 & - & 1.2 & - & 1.7 & - & 0.9 \\
\hline 96 & - & 14.8 & - & 17.0 & - & 15.4 & - & 19.4 & - & 8.1 \\
\hline 97 & - & 16.4 & - & 7.0 & - & 0.2 & - & 0.5 & - & 0.5 \\
\hline 102 & 0.4 & 0.3 & 0.7 & 0.5 & 1.0 & 0.5 & 1.0 & 0.5 & 0.8 & 0.6 \\
\hline 103 & 3.9 & 0.9 & 4.0 & 3.0 & 5.7 & 3.8 & 5.3 & 3.6 & 4.7 & 4.1 \\
\hline 104 & 4.3 & 1.9 & 5.0 & 4.0 & 2.5 & 1.4 & 3.3 & 1.2 & 2.1 & 1.6 \\
\hline 105 & 18.6 & 7.8 & 26.0 & 10.0 & 70.0 & 70.0 & 62.0 & 56.0 & 76.0 & 69.0 \\
\hline 106 & - & 2.2 & - & 4.0 & 0.4 & 1.9 & 0.7 & 3.2 & 0.7 & 5.1 \\
\hline 107 & 一 & 1.5 & 一 & 3.0 & - & 0.4 & - & 2.4 & - & 0.4 \\
\hline 108 & - & 1.8 & 一 & 2.0 & - & 0.5 & - & 1.1 & - & 0.4 \\
\hline 109 & - & 3.5 & 一 & 5.0 & - & 0.7 & - & 1.5 & 一 & 0.5 \\
\hline 110 & - & 6.4 & - & 5.0 & - & 0.2 & - & 0.7 & - & 1.1 \\
\hline 111 & - & - & - & - & - & - & - & 0.3 & - & - \\
\hline $89-106^{b}$ & 66.0 & - & 67.0 & - & 54.6 & - & 53.1 & - & 59.8 & - \\
\hline $196^{\mathrm{b}}$ & 8.8 & - & 1.5 & - & 8.0 & - & 7.3 & - & 5.0 & - \\
\hline
\end{tabular}

a In $\%\left(\sum\left[C_{7}\right]^{+}+\sum\left[C_{8}\right]^{+}\right)$; corrected for natural contributions of ${ }^{13} \mathrm{C}_{1}$ and ${ }^{13} \mathrm{C}_{2}$, but not for incomplete $D$ incorporation (see Table 1).

${ }^{b}$ In $\% \sum_{39}[\mathrm{~F}]^{+}$.

source at $70 \mathrm{eV}$ and their relative portions of the total ion current.

As expected, the $70 \mathrm{eV}$ mass spectrum of 1 differs markedly from those of the isomers 3,4 and 5 . While the latter are governed by the ions corresponding to a formal benzylic cleavage, i.e. $\left[\mathrm{C}_{8} \mathrm{H}_{9}\right]^{+}(\mathrm{m} / z 105)$ and $\left[\mathrm{C}_{7} \mathrm{H}_{7}\right]^{+}(\mathrm{m} / \mathrm{z} 91)$, the former is characterized by the very abundant $\left[\mathrm{C}_{7} \mathrm{H}_{8}\right]^{+\cdot}$ rearrangement ions. ${ }^{11}{ }^{12}$ The cycloheptatrienyl (cht) compound (2) exhibits both types of fragmentations: besides the dominating $\left[\mathrm{C}_{7} \mathrm{H}_{7}\right]^{+}$and $\left[\mathrm{C}_{8} \mathrm{H}_{9}\right]^{+}$ions significant amounts of $\left[\mathrm{C}_{7} \mathrm{H}_{8}\right]^{+\cdot}$ ions are observed. Moreover, the relative abundance of the molecular ions $[2]^{+*}$ is much lower than those of the four diaryl isomers. Thus, the $70 \mathrm{eV}$ mass spectrum of 2 reflects well its original structure, suggesting that the unstable $[2]^{+-}$molecular ions retain the structure of a 7-arylalkyl-cycloheptatriene.

By labelling one phenyl group of each isomer the contributions of the different moieties of the molecular ions to the formation of the $\mathrm{C}_{7}$ and $\mathrm{C}_{8}$ fragment ions can be distinguished. Due to its symmetry, [1a $]^{+\cdot}$ yields $\left[\mathrm{C}_{7}(\mathrm{H}, \mathrm{D})_{7}\right]^{+}$and $\left[\mathrm{C}_{7}(\mathrm{H}, \mathrm{D})_{8}\right]^{+\cdot}$ ions ${ }^{11 \mathrm{~b}}$ as well as $\left[\mathrm{C}_{8}(\mathrm{H}, \mathrm{D})_{8}\right]^{+\cdot}$ and $\left[\mathrm{C}_{8}(\mathrm{H}, \mathrm{D})_{9}\right]^{+}$ions equally from both end groups (Table 2 , after correction for incomplete labelling). In the case of the tolyl isomers $3 \mathbf{a}, \mathbf{4 a}$ and 5a, $\left[\mathrm{C}_{7}(\mathrm{H}, \mathrm{D})_{7}\right]^{+}$originates predominantly from the benzyl groups and, correspondingly, $\left[\mathrm{C}_{8}(\mathrm{H}, \mathrm{D})_{9}\right]^{+}$from the xylyl groups of the molecular ions. Thus, mainly $\left[\mathrm{C}_{7} \mathrm{H}_{2} \mathrm{D}_{5}\right]^{+}, \mathrm{m} / \mathrm{z} 96$ and $\left[\mathrm{C}_{8} \mathrm{H}_{9}\right]^{+}, \mathrm{m} / \mathrm{z}$ 105, respectively, are observed. In contrast, the cht isomer $\mathbf{2 a}$ shows considerable amounts of both $\left[\mathrm{C}_{7} \mathrm{H}_{7}\right]^{+}$and $\left[\mathrm{C}_{7} \mathrm{H}_{2} \mathrm{D}_{5}\right]^{+}$as well as $\left[\mathrm{C}_{8} \mathrm{H}_{9}\right]^{+}$and $\left[\mathrm{C}_{8} \mathrm{H}_{4} \mathrm{D}_{5}\right]^{+}$ions, 
Table 3. Relative abundances" of the $C_{7}$ and $C_{8}$ fragment ions formed from the metastable (unlabelled and labelled) molecular ions within the 1st FFR $(70 \mathrm{eV})$

\begin{tabular}{rrrrrrrrrrrr}
\hline $\mathrm{m} / \mathrm{z}$ & 1 & $1 \mathrm{c}$ & \multicolumn{1}{c}{2} & \multicolumn{1}{c}{$\mathrm{ca}$} & 3 & $3 a$ & 4 & $4 a$ & 5 & 50 \\
91 & $<0.3$ & $<0.1$ & 2.5 & 0.3 & 1.0 & - & 2.0 & - & 1.0 & - \\
92 & 71.0 & 6.5 & 6.2 & 0.5 & $\ll 0.1$ & - & $\ll 0.1$ & - & $\ll 0.1$ & - \\
93 & - & 21.0 & - & 1.5 & - & - & - & - & - & - \\
94 & - & 11.0 & - & 1.5 & - & - & - & - & - & - \\
95 & - & 5.8 & - & 1.2 & - & 50.2 & - & $<0.5$ & - & 50.1 \\
96 & - & 19.0 & - & 2.2 & - & 0.6 & - & 1.7 & - & 1.3 \\
97 & - & 12.0 & - & 0.8 & - & - & - & - & - & - \\
104 & 15.0 & 1.8 & 13.0 & 1.9 & 20.0 & 2.4 & 37.0 & 0.2 & 5.8 & 4.5 \\
105 & 13.0 & 4.9 & 78.0 & 12.0 & 79.0 & 58.0 & 61.0 & 45.0 & 93.0 & 89.0 \\
106 & - & 4.7 & - & 27.0 & - & 22.0 & - & 15.0 & - & 3.1 \\
107 & - & 4.5 & - & 17.0 & - & 5.2 & - & 7.4 & - & 0.3 \\
108 & - & 4.9 & - & 8.0 & - & 5.5 & - & 16.0 & - & 0.8 \\
109 & - & 3.4 & - & 13.0 & - & 5.8 & - & 14.0 & - & 1.3 \\
110 & - & 0.9 & - & 13.0 & - & $<0.1$ & - & 0.3 & - & $\ll 0.1$ \\
\hline
\end{tabular}

- See footnote a to Table 2.

indicating that both moieties of the molecular ions are involved in the formation of the $C_{7}$ and $C_{8}$ ions. It is interesting to note that the rearrangement ions $\left[\mathrm{C}_{7}(\mathrm{H}, \mathrm{D})_{8}\right]^{+*}(\mathrm{~m} / z 97$ and, probably in part, $\mathrm{m} / z$ 96) are formed exclusively from the benzyl but not from the cht group of $\mathbf{2 a}$.

Moreover, contrary to the behaviour of $[3 a]^{+*},[4 a]^{+-}$ and $[5 \mathbf{a}]^{+*}$, significant $H / D$ exchange is observed in the formation of both $\left[\mathrm{C}_{7}(\mathrm{H}, \mathrm{D})_{7}\right]^{+}$and $\left[\mathrm{C}_{8}(\mathrm{H}, \mathrm{D})_{9}\right]^{+}$ions from $[2 \mathrm{a}]^{+*}$. Thus, the $70 \mathrm{eV}$ mass spectra of the pentadeuterated isomers clearly confirm that the short-lived molecular ions $[2]^{+\cdot}$ exhibit a structure which is different from the structure of $[1]^{+\cdot}$ as well as those of $[3]^{+*},[4]^{+*}$ and $[5]^{+*}$.

With respect to the question of skeletal rearrangements of $[\mathbf{1}]^{+\cdot}-[5]^{+\cdot}$ the unimolecular fragmentations of metastable molecular ions are more significant. Table 3 shows the relative abundances of the $C_{7}$ and $\mathrm{C}_{8}$ ions formed within the first field free region (1st FFR), and Table 4 represents the complete sets of fragmentation channels of the unlabelled molecular ions occurring within the 2 nd FFR of a double focus-

Table 4. Relative abundances" of all fragment ions formed from metastable (unlabelled) molecular ions within the 2nd FFR (70 eV)

\begin{tabular}{|c|c|c|c|c|c|c|}
\hline $\mathrm{m} / \mathrm{z} \quad 196 \rightarrow$ & Loss of & 1 & 2 & 3 & 4 & 5 \\
\hline 181 & $\mathrm{CH}_{3} \cdot$ & 0.5 & 4.0 & 1.7 & 3.0 & 1.6 \\
\hline $169 \cdots 167$ & ${ }^{\prime} \mathrm{C}_{2}^{\prime}$ & 1.9 & 3.2 & 0.5 & 1.5 & 0.4 \\
\hline $155 \cdots 153$ & ${ }^{\prime} \mathrm{C}_{3}^{\prime}$ & 0.2 & 1.8 & - & 0.4 & - \\
\hline $142 \cdots 141$ & ${ }^{\prime} C_{4}^{\prime}$ & - & 0.7 & - & - & - \\
\hline $130 \cdots 128$ & ${ }^{\prime} \mathrm{C}_{5}^{\prime}$ & - & 0.8 & - & - & - \\
\hline 118 & $\mathrm{C}_{6} \mathrm{H}_{6}$ & 6.9 & 5.4 & 3.6 & 6.6 & 0.5 \\
\hline 105 & $\mathrm{C}_{7} \mathrm{H}_{7}^{\circ}$ & $17.0^{b}$ & $68.0^{b}$ & $70.0^{b}$ & $52.0^{b}$ & $87.0^{\mathrm{b}}$ \\
\hline 104 & $\mathrm{C}_{7} \mathrm{H}_{8}$ & $19.0^{\mathrm{b}}$ & $12.0^{b}$ & $23.0^{\mathrm{b}}$ & $35.0^{\mathrm{b}}$ & $10.0^{\mathrm{b}}$ \\
\hline 92 & $\mathrm{C}_{8} \mathrm{H}_{8}$ & 55.0 & 4.2 & - & - & - \\
\hline 91 & $\mathrm{C}_{8} \mathrm{H}_{9} \cdot$ & c & $0.2^{\mathrm{b}}$ & 0.7 & 2.1 & 0.5 \\
\hline
\end{tabular}

- In \% $\Sigma[F]^{+}$.

bough estimation due to overlapping with neighbouring peak.

'Not detectable, probably $<5 \%$ of $\left[\mathrm{C}_{7} \mathrm{H}_{8}\right]^{+\cdot}$. ing mass spectrometer in which the magnetic sector is followed by the electric sector. Obviously, the differences in the fragmentations of $[1]^{+-}-[5]^{+-}$are not cancelled out during longer lifetimes but, in contrast, become enhanced. The three different types of (original) carbon skeletons are clearly reflected by the abundance ratios (Table 3) $\left[\mathrm{C}_{7} \mathrm{H}_{7}\right]^{+} /\left[\mathrm{C}_{7} \mathrm{H}_{8}\right]^{+\cdot}(\mathrm{m} / \mathrm{z} 91$ and 92) and $\left[\mathrm{C}_{7}\right.$ ions $] /\left[\mathrm{C}_{8}\right.$ ions $]$ observed for the unlabelled isomers. On the one hand, metastable $[1]^{+\cdot}$ ions form predominantly $\left[\mathrm{C}_{7} \mathrm{H}_{8}\right]^{+\cdot}$, due to the preservation of the normal $\mathrm{C}_{3}$ aliphatic chain bearing localized activated $\mathrm{C}^{\gamma}-\mathrm{H}$ bonds. On the other hand, metastable $[3]^{+\cdot}$, $[4]^{+*}$ and $[5]^{+\cdot}$ molecular ions fragment preferably by a formal benzylic cleavage to form $\left[\mathrm{C}_{8} \mathrm{H}_{9}\right]^{+}$ions with relative abundances corresponding to the heats of formation of the expected xylyl ions. ${ }^{7}$ Distinct from $[1]^{+-}$and $[3]^{+\cdot}-[5]^{+*}$, the metastable molecular ions $[2]^{+*}$ form $\left[\mathrm{C}_{7} \mathrm{H}_{7}\right]^{+}$as well as $\left[\mathrm{C}_{7} \mathrm{H}_{8}\right]^{+\cdot}$ in significant amounts, suggesting that they preserve the aliphatic chain (bearing a localized activated $\mathrm{C}^{\gamma}-\mathrm{H}\left(\mathrm{C}^{7}-\mathrm{H}\right)$ bond) as well as a cht group as in the original structure of 2 .

Further evidence for the preservation of the three types of structures can be achieved from the mass shifts of the $C_{7}$ and $C_{8}$ fragment ions by the deuterated metastable molecular ions (Table 3). Whereas the $\left[\mathrm{C}_{7}(\mathrm{H}, \mathrm{D})_{8}\right]^{+*}$ rearrangement ions from $[\mathbf{1 a}]^{+*}$ are generated after successive five to eight exchange cycles, ${ }^{11 b}$ $\left[\mathrm{C}_{7}(\mathrm{H}, \mathrm{D})_{7}\right]^{+}$ions from $[\mathbf{3 a}]^{+\cdot},[\mathbf{4 a}]^{+\bullet}$ and $[\mathbf{5 a}]^{+\cdot}$ are formed exclusively from the original benzyl group. The occurrence of $\left.\left[\mathrm{C}_{7} \mathrm{H}_{3} \mathrm{D}_{4}\right]^{+}(m / z) 5\right)$ indicates (after correction for incomplete labelling, see Table 1) a minor H/D exchange in the molecular ions of the $m$-tolyl isomer (4a) and, to an even lower extent, in those of the $o$-tolyl isomer $3 a$. In the case of the cht isomer (2a), the pattern of the $C_{7}$ fragment ions is much more complex, indicating extensive isomerization reactions occurring prior to the formation of both $\left[\mathrm{C}_{7}(\mathrm{H}, \mathrm{D})_{7}\right]^{+}$and $\left[\mathrm{C}_{7}(\mathrm{H}, \mathrm{D})_{8}\right]^{+*}$ ions. It seems important to note that $\left[\mathrm{C}_{7}(\mathrm{H}, \mathrm{D})_{7}\right]^{+}$ions from $[2 \mathrm{a}]^{+\cdot}$ originate only in part (if at all) from the benzyl group. Thus, in contrast to the tolyl groups of $[3]^{+*},[4]^{+*}$ and $[5]^{+\cdot}$, the cht group of $[2]^{+\cdot}$ is involved on the formation of the $\left[\mathrm{C}_{7} \mathrm{H}_{7}\right]^{+}$ions.

The abundance patterns of the $\mathrm{C}_{8}$ ions reveal further interesting differences with respect to the origin of these ions. As expected, in the case of $[\mathbf{1 a}]^{+\cdot}$ both $\left[\mathrm{C}_{8}(\mathrm{H}, \mathrm{D})_{8}\right]^{+}$and $\left[\mathrm{C}_{8}(\mathrm{H}, \mathrm{D})_{9}\right]^{+}$are formed equally from both phenethyl groups of the parent ions, the abundance pattern (Table 3 ) being qualitatively consistent with the specific $H / D$ migrations that precede the formation of $\left[\mathrm{C}_{7}(\mathrm{H}, \mathrm{D})_{8}\right]^{+\cdot}$ (and $\left[\mathrm{C}_{7}(\mathrm{H}\right.$, D) $\left.\left.{ }_{7}\right]^{+}\right){ }^{11 \mathrm{~b}}$ The relatively low abundances of $\left[\mathrm{C}_{8} \mathrm{H}_{8}\right]^{+\cdot}$ $\left(m / z\right.$ 104) as well as $\left[\mathrm{C}_{8} \mathrm{H}_{4} \mathrm{D}_{5}\right]^{+}(m / z 110)$ point to a comparably efficient $\mathrm{H} / \mathrm{D}$ exchange prior to both types of fragmentations.

Contrary to [1a] ${ }^{+\cdot}$, the molecular ions of the $o$ - and $p$-tolyl isomers $\left([\mathbf{3 a}]^{+\cdot}\right.$ and $\left.[5 \mathbf{a}]^{+\cdot}\right)$ form all the $\left[\mathrm{C}_{8}(\mathrm{H}, \mathrm{D})_{9}\right]^{+}$ions from the originally unlabelled xylyl groups and none from the phenethyl groups. Similarly, the abundance of $\left[\mathrm{C}_{8} \mathrm{H}_{4} \mathrm{D}_{5}\right]^{+}(\mathrm{m} / \mathrm{z} 110)$ from the meta isomer $[4 a]^{+*}$ is extremely low. These observations suggest a H/D exchange between the arylaliphatic moieties of the tolyl isomers playing a minor part in 

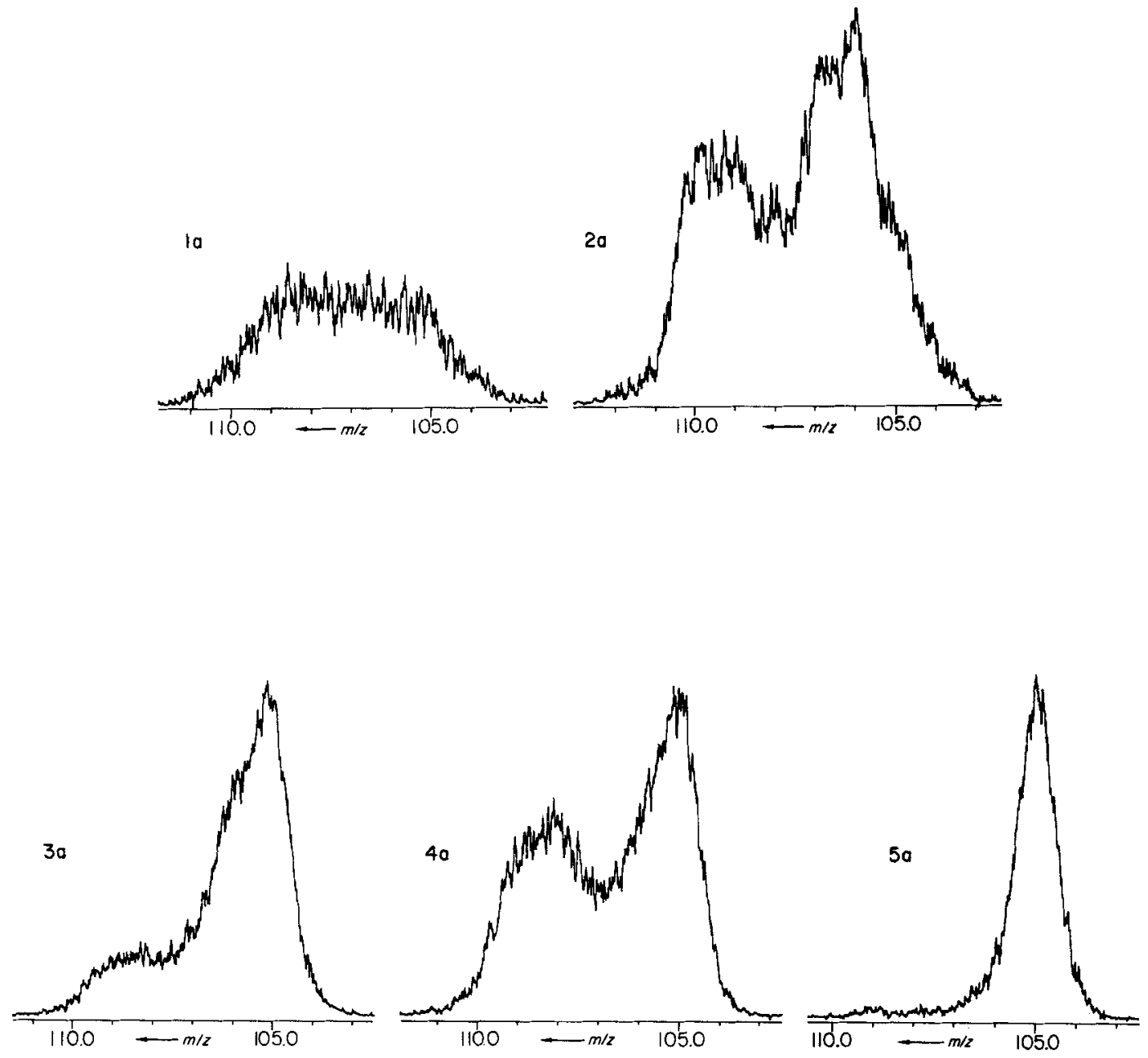

Figure 1. Peak groups of $\left[C_{8}(H, D)_{8}\right]^{+^{+}}$and $\left[C_{8}(H, D)_{9}\right]^{+}$ions formed from metastable molecular ions $[1 a]^{+^{+}}-[5 a]^{+^{*}}$ in the 2nd FFR.

the para isomer $[\mathbf{5 a}]^{+\cdot}$ but taking on increasing significance in the ortho and meta isomers $[3 \mathbf{a}]^{+\cdot}$ and $[4 \mathbf{a}]^{+*}$ (cf. especially $\left[\mathrm{C}_{8} \mathrm{H}_{8} \mathrm{D}\right]^{+}\left(\mathrm{m} / z\right.$ 106) and $\left[\mathrm{C}_{8} \mathrm{H}_{7} \mathrm{D}_{2}\right]^{+}$ $(m / z 107)$ vs. $\left[\mathrm{C}_{8} \mathrm{H}_{9}\right]^{+}(\mathrm{m} / z$ 105)). In contrast to the $\left[\mathrm{C}_{8}(\mathrm{H}, \mathrm{D})_{9}\right]^{+}$ions, the $\left[\mathrm{C}_{8}(\mathrm{H}, \mathrm{D})_{8}\right]^{+\cdot}$ ions from $[3 \mathrm{a}]^{+\cdot}$ and $[\mathbf{4 a}]^{+}$originate predominantly from the (labelled) phenethyl groups (cf. $\left.\left[\mathrm{C}_{8} \mathrm{H}_{3} \mathrm{D}_{5}\right]^{+*}(m / z) 109\right)$ vs. $\left[\mathrm{C}_{8} \mathrm{H}_{8}\right]^{+\cdot}(\mathrm{m} / \mathrm{z}$ 104)). Again differing from these two isomers, $[\mathbf{5 a}]^{+\cdot}$ exhibits a preponderant formation of unlabelled $\left[\mathrm{C}_{8} \mathrm{H}_{8}\right]^{+*}$, hence being generated from the $p$-xylyl group of this isomer.

As compared with the tolyl isomers the abundance pattern of the $\mathrm{C}_{8}$ ions obtained from the cht isomer $[2 \mathrm{a}]^{+*}$ indicates considerably more $\mathrm{H} / \mathrm{D}$ exchange prior to the formation of $\left[\mathrm{C}_{8}(\mathrm{H}, \mathrm{D})_{9}\right]^{+}$and probably $\left[\mathrm{C}_{8}(\mathrm{H}, \mathrm{D})_{8}\right]^{+\cdot}$ ions. Contrary to the latter (vide supra), the $\left[\mathrm{C}_{8} \mathrm{H}_{4} \mathrm{D}_{5}\right]^{+}$ions $\left(\mathrm{m} / z\right.$ 110) from $[2 \mathrm{a}]^{+\cdot}$ are remarkably abundant, showing that the $\left[\mathrm{C}_{8}(\mathrm{H}, \mathrm{D})_{9}\right]^{+}$ions are formed in comparable amounts from the olefinic and the aromatic parts of the molecular ions. The same might be true for the $\left[\mathrm{C}_{8}(\mathrm{H}, \mathrm{D})_{8}\right]^{+\cdot}$ ions, but most probably the major part of them originates from the cht moiety of $[\mathbf{2 a}]^{+}$.
The fragmentation of the metastable molecular ions within the 2 nd FFR corresponds to the above results. Figure 1 represents the $C_{8}$ ion region of the ion kinetic energy spectrum of the pentadeuterated molecular ions $[1 \mathrm{a}]^{+-}-[5 \mathrm{a}]^{+\cdot}$. Although neighbouring peaks are not separated, the patterns reflect the drastic differences between each of the five isomers. As a special peculiarity besides the characteristic differences between the tolyl isomers $[3 a]^{+\cdot}-[5 a]^{+*}$, the cht isomer $[2 \mathrm{a}]^{+-}$forms considerable amounts of $\left[\mathrm{C}_{8} \mathrm{H}_{4} \mathrm{D}_{5}\right]^{+}(\mathrm{m} / \mathrm{z}$ $110)$ and $\left[\mathrm{C}_{8} \mathrm{H}_{8}\right]^{+\cdot}(m / z 104)$, again contrasting with $[3 \mathbf{a}]^{+\cdot},[4 \mathbf{a}]^{+\cdot}$ and $[5 \mathrm{a}]^{+\cdot}$.

The whole of the various fragmentation reactions of the metastable (unlabelled) molecular ions within the 2nd FFR are shown in Table 4. As expected, the relative abundances of the $C_{7}$ and $C_{8}$ ions correspond closely to those observed in the 1st FFR (Table 3). Apart from this the loss of small neutrals from $[2]^{+-}$is significantly more pronounced than from the other isomers. Indeed, this observation is consistent with the mass spectral behaviour of olefinic and aromatic compounds. $^{13}$

Summarizing the results at this point reveals that 
Table 5. Ionization $I(M)$ and appearance energies $A\left([F]^{+}\right)$of the unlabelled isomers 1-5 in $\mathbf{e V}^{\mathbf{2}}$

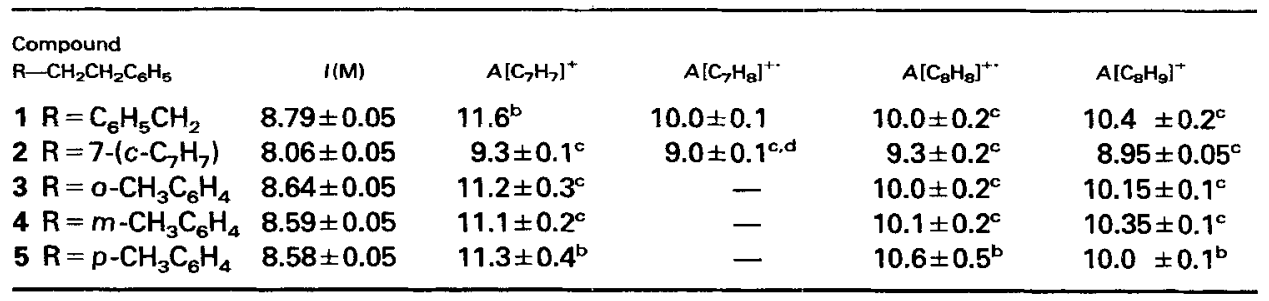

Reference: $/\left(\mathrm{CH}_{3} \mathrm{l}\right)=9.50 \mathrm{eV}$, standard deviation better than values given.

b Curve tails significantly, not parallel to ionization efficiency curve of standard.

c As footnote $b$, but curves of fragment ions mutually parallel.

${ }^{d}$ Corrected for natural contribution of $\left[{ }^{12} \mathrm{C}_{6}{ }^{13} \mathrm{CH}_{7}\right]^{+}$at $\mathrm{m} / \mathrm{z} 92$ (c. $-0.1 \mathrm{eV}$ ).

each of the five isomeric molecular ions exhibit-even after a lifetime of $>10^{-5} \mathrm{~s}$-characteristic differences in both their fragmentation and their isomerization $(\mathrm{H}$ rearrangement) behaviour, reflecting the structures of the original carbon skeletons. In particular, the cht isomer $[2]^{+\cdot}$ reacts quite differently from $[1]^{+*},[3]^{+\cdot}$ $[\mathbf{4}]^{+\cdot}$ and $[\mathbf{5}]^{+\cdot}$.

\section{Ionization and appearance energies}

In order to estimate the energy requirements for the formation of the $C_{7}$ and $C_{8}$ fragments, the ionization and appearance energies, $I(\mathrm{M})$ and $A\left([F]^{+}\right)$, have been determined (Table 5). The ionization energies are well in the order expected for ionization of the original benzyl, cht and tolyl groups, respectively.

The appearance energies are in line throughout with the relative abundances of the corresponding ions formed from the metastable molecular ions (Tables 3 and 4). ${ }^{14}$ Accordingly, 2 is the only isomer which exhibits approximately equal appearance energies for all of the four $\mathrm{C}_{7}$ and $\mathrm{C}_{8}$ fragment ions. Contrary to this, the $A\left(\left[\mathrm{C}_{7} \mathrm{H}_{7}\right]^{+}\right)$values for 1 and 3-5 should exceed the true 'thermodynamic' energy requirements by far due to considerable competitive shifts; hence they are not taken into account in the estimation of the isomerization barrier (vide infra). Unfortunately, the ionization efficiency curves of the fragment ions are not parallel to those of the standard, so that the other $\mathrm{A}\left([\mathrm{F}]^{+}\right)$values might be also too high to a certain degree. ${ }^{15}$ It can be assumed, however, that this source of error does not invalidate seriously the following conclusions (see also Experimental).

The release of kinetic energy ${ }^{16}$ in the formation of $\left[\mathrm{C}_{7} \mathrm{H}_{8}\right]^{+-},\left[\mathrm{C}_{8} \mathrm{H}_{8}\right]^{+\cdot}$ and $\left[\mathrm{C}_{8} \mathrm{H}_{9}\right]^{+}$from the metastable molecular ions $[1]^{+\cdot}-[5]^{+\cdot}$ is found to be small $(17-$ $21 \mathrm{meV}, \pm 10 \%$, as determined from the peak width at half-height). Thus, these fragmentation reactions occur without significantly large reverse activation energies and without being preceded by a rate-determining isomerization process. ${ }^{8 \mathrm{~b}, 8 \mathrm{~d}}$

\section{DISCUSSION}

Neglecting a detailed discussion of the energy data the fragmentation of the metastable molecular ions suggests that each of the five isomers $[1]^{+\cdot}-[5]^{+*}$ retains its original carbon skeleton. In every case, however, various isomerization reactions do occur via hydrogen shift and/or 'long range hydrogen transfer' ${ }^{11 \mathrm{~b}}$ reactions. Whereas the latter are well known, especially from molecular ions which contain both aromatic and long chain aliphatic groups, ${ }^{17}$ the former are characteristic for the positive (radical) ions of olefinic hydrocarbons as e.g. cyclohexene ${ }^{18 a}$ and isobutene. ${ }^{18 b}$ Thus, it is not surprising that the cht isomer $[2 \mathbf{a}]^{+}$. reveals a markedly high degree of $H / D$ exchange. According to Dewar and Landman, ${ }^{10 a}$ the ionized cht ring should suffer rapid 1,2-hydrogen shifts (instead of the unfavourable ${ }^{10 c} 1,5$ shifts which, in turn, may occur thermally prior to ionization ${ }^{19}$ ) requiring only $c$. $14 \mathrm{kcal} \mathrm{mol}^{-1}$ activation energy. Furthermore, $[2]^{+\cdot}$, similarly to $[1]^{+\cdot},{ }^{11}$ reacts as an alkyl benzene with a localized activated ${ }^{20} \mathrm{C}^{\gamma}-\mathrm{H}$ (as well as $\mathrm{C}^{\alpha}-\mathrm{H}$ ) bond(s) exchanging hydrogen between the phenyl and the cht ring (Table 3). Scheme 1 illustrates some of these hydrogen migrations.

With respect to skeletal isomerizations the present results strictly exclude only the conversion of $[1]^{+\cdot}$ to $[2]^{+-}$(as well as to $[3]^{+\cdot},[4]^{+\cdot}$ and $[5]^{+*}$ ) and that of $[3]^{+-},[4]^{+\cdot}$ and $[5]^{+\cdot}$ to $[2]^{+\cdot}$ (as well as to $[\mathbf{1}]^{+\cdot}$ ). However, the results do not exclude a partial ring contraction of the cht moiety of $[2]^{+*}$, i.e. skeletal isomerization of $[2]^{+\cdot}$ to form $[1]^{+\cdot}$ and/or $[3]^{+*},[4]^{+*}$ and $[5]^{+\cdot}$. Metastable molecular ions of $7-$ methylcycloheptatriene, ${ }^{22}$ closely related to $[2]^{+*}$, indeed show considerable hydrogen and skeletal isomerization prior to loss of $\mathrm{CH}_{3}$.

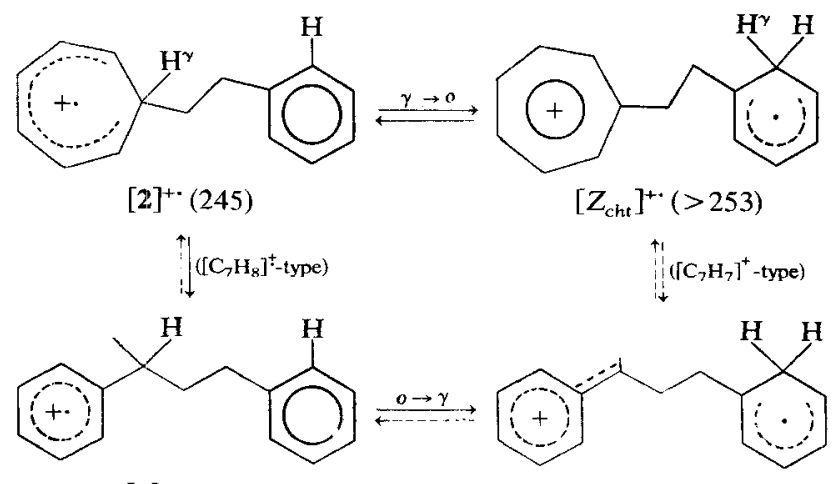

$$
[1]^{+\cdot}(232)
$$$$
\left[Z_{\vee}\right]^{+\cdot}(>252)
$$

Scheme 1. $\left[\mathrm{C}_{7} \mathrm{H}_{8}\right]^{+-}$-type and $\left[\mathrm{C}_{7} \mathrm{H}_{7}\right]^{+}$-type skeletal isomerization of $[2]^{+\cdot}$ to its diaryl isomers, e.g. $[1]^{+*}$. Starting from low energy $[1]^{+*}$ rearrangements marked with dashed arrows do not occur for energetic reasons (see text). Values refer to the heats of formation (in kcal mol "1) of the corresponding ions (cf. Scheme 5 in Ref. 11b). 


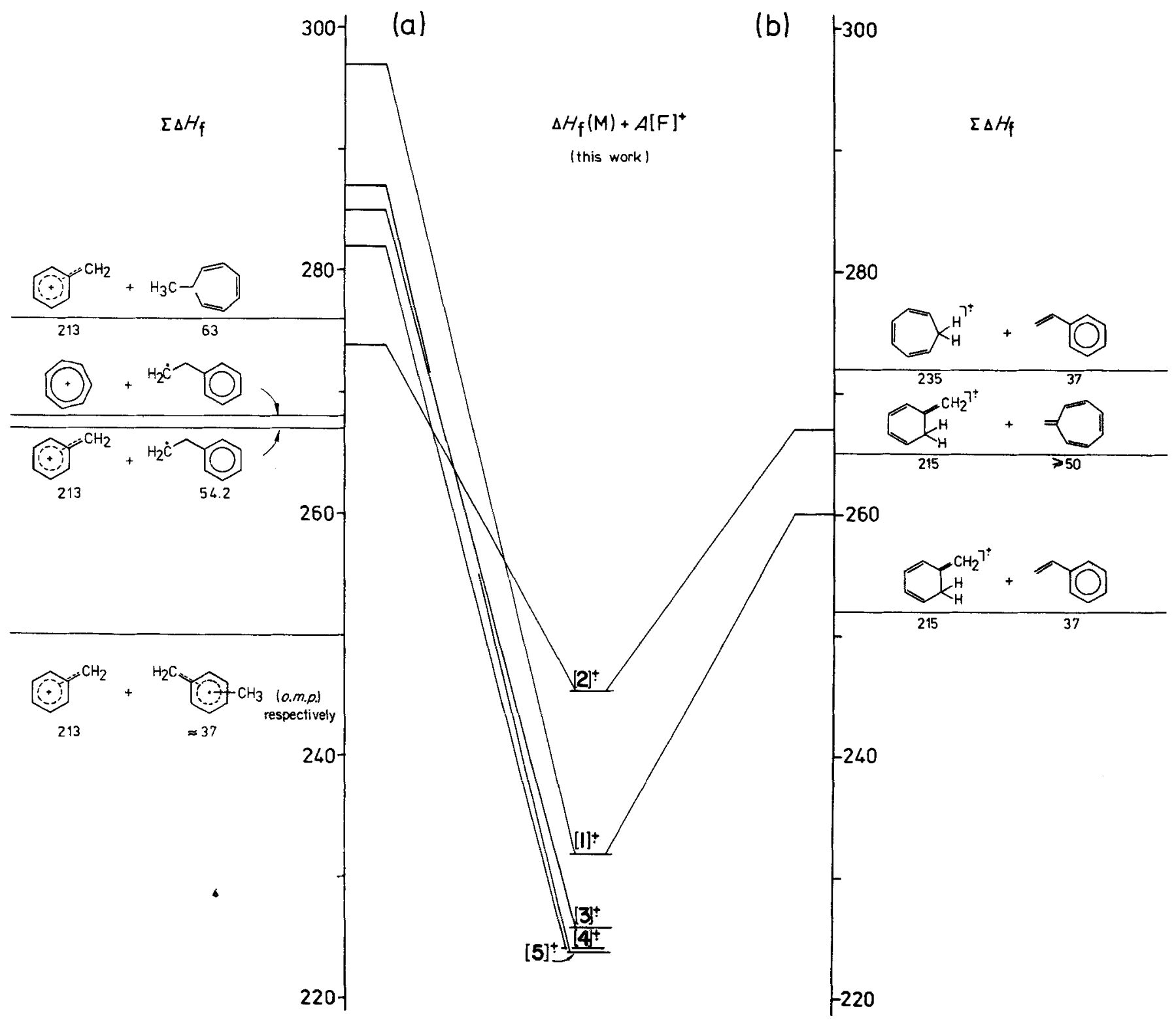

Figure 2. Heats of formation of the molecular ions $[1]^{+\cdot}-[5]^{+\cdot}$ and of the transition states for fragmentation to $(a)\left[C_{7} H_{7}\right]^{+}+C_{8} H_{9}$ and (b) $\left[\mathrm{C}_{7} \mathrm{H}_{8}\right]^{+\cdot}+\mathrm{C}_{8} \mathrm{H}_{8}$. The latter energy levels are contrasted with the thermochemical energy levels expected for the combined heats of formation of various fragmentation products (see Appendix, all values in $\mathrm{kcal} \mathrm{mol}^{-1}$ ).

An answer to this problem is achieved by contrasting the energy requirements found for the various fragmentation channels of $[\mathbf{1}]^{+\cdot}-[\mathbf{5}]^{+*}$ (Table 5) to the minimum (combined) energy contents of the corresponding charged and neutral fragments. Figures 2 and 3 show schematically an estimation of the heats of formation of the molecular ions, $\Delta H_{\mathrm{f}}\left([\mathrm{M}]^{+*}\right)=$ $\Delta H_{f}(\mathrm{M})+I(\mathrm{M})$, the apparent heats of formation of the highest transition states involved in each of the four fragmentation pathways, $\Delta H_{\mathrm{f}}\left([\mathrm{M}]^{+\cdot}\right)^{\ddagger}=\Delta H_{\mathrm{f}}(\mathrm{M})+$ $A[\mathrm{~F}]^{+}$, and the approximate heats of formation of the corresponding pair of fragments, $\Delta H_{\mathrm{f}}\left([\mathrm{F}]^{+}\right)+\Delta H_{\mathrm{f}}(\mathrm{N})$ (termed $\sum \Delta H_{f}$ ). (For the various values used for $\Delta H_{\mathrm{f}}(\mathrm{M}), \Delta H_{\mathrm{f}}\left([\mathrm{F}]^{+}\right)$and $\Delta H_{\mathrm{f}}(\mathrm{N})$, see Appendix.) Despite considerable uncertainties in some energetic data a decision can be made as to whether or not skeletal isomerization occurs.

In the case of the diaryl isomers $[1]^{+\cdot}$ and $[3]^{+\cdot}-[5]^{+\cdot}$ the energy requirements found for generation of the $\mathrm{C}_{7}$ ions are consistent throughout with the formation of 6-membered fragments. Although these isomers could have isomerized to $[2]^{+*}$ prior to the formation of the $\left[\mathrm{C}_{7} \mathrm{H}_{7}\right]^{+} / \mathrm{C}_{8} \mathrm{H}_{9}{ }^{*}$ pair it seems more reasonable to assume large competitive shifts due to the existence of more favourable fragmentation (and, especially in the case of $[1]^{+\cdot}, 11 \mathrm{a}, 1 \mathrm{~b}$ isomerization) pathways. The energetic consideration provides further evidence of the fact ${ }^{11 b}$ that $[1]^{+*}$ molecular ions do not rearrange to a cht-type isomer, since neither $\mathrm{C}_{7} \mathrm{H}_{8}$ nor $\mathrm{C}_{8} \mathrm{H}_{8}$ (charged as well as neutral) fragments can exhibit 7-membered structures (Figs. 2 and 3).

Including the fragmentation of the metastable molecular ions (Tables 3 and 4) the possibility that the ortho and meta isomers $[3]^{+\cdot}$ and $[4]^{+*}$ undergo a ring expansion reaction is clearly ruled out. In both cases $\left[\mathrm{C}_{8} \mathrm{H}_{8}\right]^{+*}$ ions $(\mathrm{m} / \mathrm{z} 104)$ originate mainly from the unsubstituted phenyl nucleus; consequently, the $\left[\mathrm{C}_{8} \mathrm{H}_{8}\right]^{+-} / \mathrm{C}_{7} \mathrm{H}_{8}$ pair cannot comprise an ionized heptafulvene or a neutral cycloheptatriene (Fig. 3). The same should hold for the para isomer $[5]^{+*}$, which 


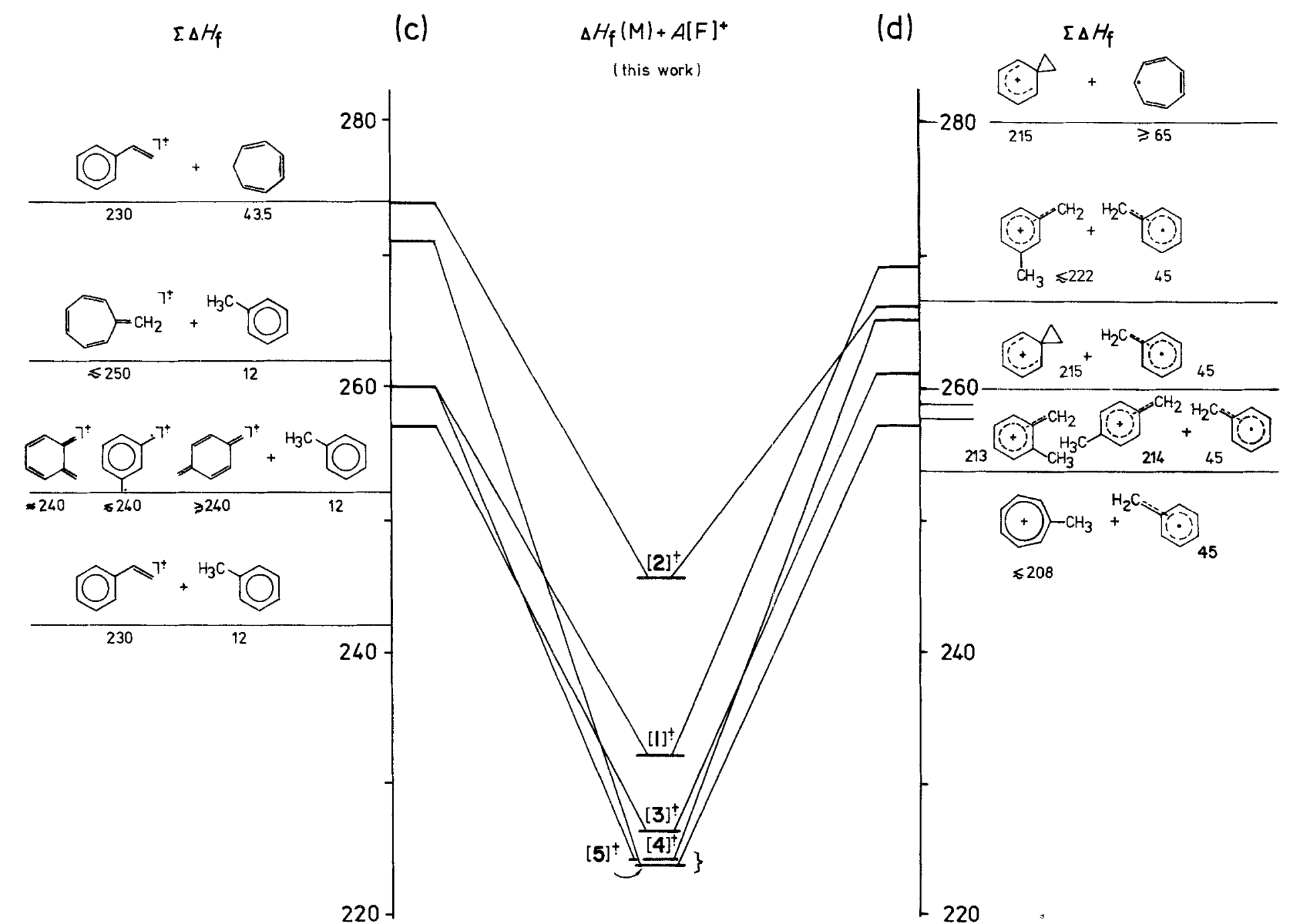

Figure 3. Heats of formation of the molecular ions $[1]^{+\cdot}-[5]^{+\cdot}$ and of the transition states for fragmentation $(c)\left[\mathrm{C}_{8} \mathrm{H}_{8}\right]^{+\cdot}+\mathrm{C}_{7} \mathrm{H}_{8}$ and $(\mathrm{d})$ $\left[\mathrm{C}_{8} \mathrm{H}_{8}\right]^{+}+\mathrm{C}_{7} \mathrm{H}_{7}$. The latter energy levels are contrasted with the thermochemical energy levels expected for the combined heats of formation of various fragmentation products (see Appendix, all values in $\mathrm{kcal} \mathrm{mol}^{-1}$ ).

surprisingly forms $\left[\mathrm{C}_{8} \mathrm{H}_{8}\right]^{+\cdot}$ mostly from the xylyl group. In this case the formation of ionized heptafulvene cannot be excluded strictly though a preservation of the $p$-xylyl group of $[5]^{+*}$, generating ionized $p$ xylylene, is much more likely (vide infra).

The energy requirements found for the formation of $\left[\mathrm{C}_{8} \mathrm{H}_{9}\right]^{+\cdot}$ ions $(m / z \quad 105)$ from either $[1]^{+\cdot}$ and $[3]^{+*}-$ $[5]^{+\cdot}$ are consistent with those expected for the fragmentation of the original structures (Fig. 3). In these cases, however, the formation of energetically most favourable methyltropylium ions (from a hypothetical cht-type isomer assuming appropriate hydrogen shifts) cannot be excluded from a combination of the slow fragmentation (Tables 3 and 4) and the energetic data alone. The only but yet conclusive evidence for the preservation of the original carbon skeleton in $[3]^{+*}$, $[4]^{+*}$ and $[5]^{+*}$ is provided by the formation of considerable amounts of $\left[\mathrm{C}_{8} \mathrm{H}_{9}\right]^{+*}$ from the phenethyl moiety of the cht isomer $[2]^{+\cdot}$ which does not occur in the case of the tolyl isomers.

Thus, both the route and the energy requirements of the fragmentation exclude a skeletal isomerization of the four purely arylaliphatic isomers $[\mathbf{1}]^{+*},[3]^{+*},[4]^{+*}$ and $[5]^{+*}$ prior to formation of the $C_{7}$ and $C_{8}$ ions. This is not the case for $[2]^{+*}$. Obviously, some of the activated complexes involved in the fragmentation pathways of this isomer exhibit heats of formation which fall short of the (combined) energy contents of the corresponding fragments if no contraction of the cht ring is anticipated (Figs. 2 and 3). Bearing in mind that appearance energy measurements yield principally an upper limit to the (true) energy requirement of a fragmentation reaction, ${ }^{23}$ it seems doubtful whether all of the $C_{7}$ and $C_{8}$ fragments (whether charged or neutral) are generated from nonisomerized, cht-type structures. This is most obvious for the formation of $\left[\mathrm{C}_{8} \mathrm{H}_{9}\right]^{+} / \mathrm{C}_{7} \mathrm{H}_{7}{ }^{*}$ (Fig. 3). Even if $\left[\mathrm{C}_{8} \mathrm{H}_{9}\right]^{+}$is assumed to be the $\alpha$-phenethyl cation instead of ethylenebenzenium, and even if the recent values of $\Delta \mathrm{H}_{\mathrm{f}}\left(\left[c^{6}-\mathrm{C}_{6} \mathrm{H}_{5} \mathrm{CHCH}_{3}\right]^{+}\right)=202.9 \mathrm{kcal} \mathrm{mol}^{-1}$ ${ }^{21 \dagger}$ and $202.6 \mathrm{kcal} \mathrm{mol}^{-1} 24$ are used instead of the formerly accepted one $\left(\approx 218 \mathrm{kcal} \mathrm{mol}^{-1}{ }^{7}\right)$ the discrepancy does not vanish conclusively, all the more since possibly $\Delta H_{f}\left(c-C_{7} H_{7}{ }^{\circ}\right)$ exceeds ${ }^{25}$ the formerly accepted value $\left(65 \mathrm{kcal} \mathrm{mol}^{-1} 7 \mathrm{a}\right)$. Furthermore, following the argument ${ }^{14}$ that competing fragmentations of metastable ions should exhibit similar activation energies $\left(E^{0} \leq A\left([\mathrm{~F}]^{+}\right)-I(\mathrm{M})\right.$, which is found for $[2]^{+\cdot}$ in $\dagger$ The authors thank a referee for his comment concerning $\Delta H_{\mathrm{f}}([c$ $\left.\mathrm{C}_{6} \mathrm{H}_{5} \mathrm{CHCH}_{3}\right]^{+}$). 
particular), it appears impossible that the two thresholds for the formation of $\left[\mathrm{C}_{8} \mathrm{H}_{9}\right]^{+}$(e.g. $[2 \mathrm{a}]^{+\cdot} \rightarrow$ $\left[\mathrm{C}_{8} \mathrm{H}_{9}\right]^{+}+\mathrm{C}_{7} \mathrm{H}_{2} \mathrm{D}_{5}^{*}$ and $\left.[2 \mathbf{a}]^{+*} \rightarrow\left[\mathrm{C}_{8} \mathrm{H}_{4} \mathrm{D}_{5}\right]^{+}+\mathrm{C}_{7} \mathrm{H}_{7}^{*}\right)$ should be as different as might be suggested from Fig. 3.

A similar, although less pronounced effect may be discussed for $[2]^{+\cdot} \rightarrow\left[\mathrm{C}_{7} \mathrm{H}_{8}\right]^{+\cdot}+\mathrm{C}_{8} \mathrm{H}_{8}$ and perhaps $[2]^{+\cdot} \rightarrow\left[\mathrm{C}_{7} \mathrm{H}_{7}\right]^{+}+\mathrm{C}_{8} \mathrm{H}_{9}{ }^{-}$(Fig. 2). Admittedly, for both reactions $\Delta H_{f}(Z)+A[F]^{+}$agree quite well with the minimum energy requirements expected for cht-type parent ions, taking both $A\left(\left[\mathrm{C}_{7} \mathrm{H}_{8}\right]^{+\cdot}\right)$ and $A\left(\left[\mathrm{C}_{7} \mathrm{H}_{7}\right]^{+}\right)$ as a mean value due to two slightly different heats of reaction. However, in the light of the general arguments mentioned above and of the uncertainty of $\Delta H_{f}$ (heptafulvene) (see Appendix), [2] ${ }^{+\cdot}$ must be assumed to isomerize in part to $[1]^{+\cdot}$ and/or $[3]^{+\cdot}-[5]^{+\cdot}$.

Before discussing the height of the energy barrier for the skeletal isomerization in the system $[\mathbf{1}]^{+-}-[\mathbf{5}]^{+*}$, it should be noted that $[2]^{+\cdot}$-as the unique isomercould suffer a rearrangement avoiding skeletal isomerization(s) of the open shell $\left(\left[\mathrm{C}_{7} \mathrm{H}_{8}\right]^{+\cdot}\right.$-type) structure itself. As shown in Scheme 1, [2 $]^{+\cdot}$ should isomerize readily via $\gamma \rightarrow$ ortho $\mathrm{H}^{*}$ transfer to an intermediate $\left[Z_{\text {cht }}\right]^{+\cdot}$ (cf. $[1]^{+\cdot} \rightarrow\left(Z_{\mathrm{a}}\right]^{+\cdot}$, Ref. $11 \mathrm{~b}$ ). $\left[Z_{\text {cht }}\right]^{+\cdot}$ can be assumed to isomerize as a tropylium ion, i.e. as a (quasi) closed shell species, to form the corresponding tautomers of $[1]^{+*}$ (shown in Scheme 1), $[3]^{+*},[4]^{+\cdot}$ and $[5]^{+\cdot}$ (whose heats of formation should be similar to $\Delta H_{\mathrm{f}}\left(\left[Z_{\text {cht }}\right]^{+*}\right)$, cf. $\left[Z^{\gamma}\right]^{+-}$in Ref. 11b). Thus, the partial ' $\left[\mathrm{C}_{7} \mathrm{H}_{8}\right]^{+-}$-type' isomerization of $[2]^{+\cdot}$ could be considered to be in fact the ' $\left[\mathrm{C}_{7} \mathrm{H}_{7}\right]^{+}$-type'. However, following the recent results of Cone, Dewar and Landman, ${ }^{10 a}$ the energy requirement for the rearrangement of a benzyl ion to tropylium should be $33 \mathrm{kcal} \mathrm{mol}^{-1}$ (starting from the benzyl ion), hence excluding this mechanistic possibility for energetic reasons.

On the basis of the above results and arguments the height of the energy barrier for the $\left[\mathrm{C}_{7} \mathrm{H}_{8}\right]^{+\cdot}$-type isomerization can be estimated. Figure 4 shows a simplified energy profile for the interconversion of $[1]^{+-}-[5]^{+\cdot}$ and the (apparent) energy barriers of their various fragmentation reactions. For example, the threshold energy for the isomerization $[1]^{++} \rightleftharpoons[2]^{+*}$ must exceed significantly those for the fragmentations $[1]^{+\cdot} \rightarrow\left[\mathrm{C}_{7} \mathrm{H}_{8}\right]^{+\cdot}+\mathrm{C}_{8} \mathrm{H}_{8}$ and $[1]^{+\cdot} \rightarrow\left[\mathrm{C}_{8} \mathrm{H}_{8}\right]^{+\cdot}+\mathrm{C}_{7} \mathrm{H}_{8}$ $\left(260 \mathrm{kcal} \mathrm{mol}^{-1}\right.$, cf. $b$ and $c$, respectively, in Figs. 2-4). Similarly, the thresholds for the isomerizations $[2]^{+\cdot} \rightleftharpoons$ $[3]^{+\cdot}$ and $[2]^{+\cdot} \rightleftharpoons[5]^{+\cdot}$ must clearly be higher than 261 and $257 \mathrm{kcal} \mathrm{mol}^{-1}$, respectively (cf. formation of $\left[\mathrm{C}_{8} \mathrm{H}_{9}\right]^{+}+\mathrm{C}_{7} \mathrm{H}_{7}^{\cdot}, d$ in Figs. 2-4). If $[2]^{+}$, on its own, did not suffer any ring contraction at all, the isomerization threshold for $[2]^{+\cdot} \rightleftharpoons[1]^{+\cdot}$ should be higher than c. $274 \mathrm{kcal} \mathrm{mol}^{-1}$. However, as a partial ring contraction does occur, the transition states for isomerization and for fragmentation should have very similar heats of formation. Hence it seems reasonable to estimate a value of $265 \mathrm{kcal} \mathrm{mol}^{-1}$ as an approximate lower limit to the heat of formation of the highest transition states involved in the skeletal isomerization reactions $[1]^{+\cdot} \rightleftharpoons[2]^{+^{+}},[2]^{+\cdot} \rightleftharpoons[3]^{+\cdot}$, $[2]^{+\cdot} \rightleftharpoons[4]^{+\cdot}$ and $[2]^{+\cdot} \rightleftharpoons[5]^{+\cdot}$. Possibly this value is too low by c. $5 \mathrm{kcal} \mathrm{mol}^{-1}$, for a value of c. $270 \mathrm{kcal} \mathrm{mol}^{-1}$ would still allow the metastable molecular ions to travel in part across the isomerization barrier. This would account for the relatively high threshold energies for $[2]^{+\cdot} \rightarrow\left[\mathrm{C}_{8} \mathrm{H}_{8}\right]^{+\cdot}+\mathrm{C}_{7} \mathrm{H}_{8}(c)$ and also for $[4]^{+\cdot} \rightarrow$ $\left[\mathrm{C}_{8} \mathrm{H}_{9}\right]^{+}+\mathrm{C}_{7} \mathrm{H}_{7}{ }^{\cdot}(d)$. However, the observed appearance energies may be too high to some extent (particularly that of the latter reaction) because of some kinetic shift and of different slopes of the ionization efficiency curves (Table 5). Thus, the estimated lower limit $\left(265 \mathrm{kcal} \mathrm{mol}^{-1}\right)$ might exhibit an error of $c$. $\pm 5 \mathrm{kcal} \mathrm{mol}^{-1}$, besides that arising from the limited reproducibility of the appearance energy data.

Expressing the height of the isomerization barrier $\left(E_{\text {isom }}^{\neq}\right)$independently, i.e. as a characteristic feature for the (substituted) $\left[\mathrm{C}_{7} \mathrm{H}_{8}\right]^{+\cdot}$ grouping, the above estimate yields $E_{\text {isom }}^{\neq}>33 \pm 5 \mathrm{kcal} \mathrm{mol}^{-1}$ for a monoalkylbenzene, $E_{\text {isom }}^{\neq}>20 \pm 5 \mathrm{kcal} \mathrm{mol}^{-1}$ for a 7 -alkylcycloheptatriene and $E_{\text {isom }}^{\neq}>40 \pm 5 \mathrm{kcal} \mathrm{mol}^{-1}$ for a dialkylbenzene radical cation. Complementary to these lower limits, upper limits to the isomerization barrier can be estimated from energy data known for favourable fragmentation reactions of $\left[\mathrm{C}_{7} \mathrm{H}_{8}\right]^{+-}$-type radical cations which do undergo skeletal isomerization. Some selected examples are compiled in Table 6. The energy requirements for loss of $\mathrm{H}^{*}$ from the molecular ions of toluene, the higher alkylbenzenes and diphenylmethane suggest an upper limit of $E_{\text {isom }}^{\neq}<$ $58 \mathrm{kcal} \mathrm{mol}^{-1}$. The threshold for loss of $\mathrm{CH}_{3}$ from the ethylbenzene radical ion is still considerably lower, but unfortunately there is no conclusive evidence as to whether the metastable, i.e. low energy, ions undergo the ring expansion. It was argued by Yeo and Wil$\operatorname{liams}^{26}$ that the isomerization barrier for ethylbenzene would be $E_{\text {isom }}^{\neq}>2.3 \mathrm{eV}=53 \mathrm{kcal} \mathrm{mol}^{-1}$, based on the specific loss of the original $\beta-\mathrm{CH}_{3}$ group from the unstable molecular ions formed at $70 \mathrm{eV} .^{1}$ It is obvious, however, that this is not sufficient evidence for an estimation of $E_{\text {isom }}^{\neq}$since metastable ions might nevertheless have isomerized prior to $\mathrm{CH}_{3}{ }^{\circ}$ loss (cf. Ref. 27). This is supported by the finding that the metastable molecular ions of 1-chloro- ${ }^{28 a}$ and 1bromo-4-ethylbenzene $\mathrm{e}^{28 \mathrm{a}, 28 \mathrm{~b}}$ do isomerize to the corresponding cht isomers.

Whereas it follows from these arguments that $E_{\text {isom }}^{\neq}<50 \mathrm{kcal} \mathrm{mol}^{-1}$ (Table 6), the appearance energies which can be deduced from Dunbar's photodissociation curves ${ }^{29}$ point to an upper limit of $E_{\text {isom }}^{\neq}<$ $45 \mathrm{kcal} \mathrm{mol}^{-1}$ for monoalkylbenzenes and $E_{\text {isom }}^{\neq}<$ $53 \mathrm{kcal} \mathrm{mol}^{-1}$ for dialkylbenzenes.

Thus, it is possible to bracket the true height of the isomerization barrier from experimental evidence. It is very interesting that the range of $33<E_{\text {isom }}^{\neq}<$ $45 \mathrm{kcal} \mathrm{mol}^{-1}$ deduced in the present study for monoalkylbenzenes agrees very well with Dewar's and Landman's semi-empirically calculated ('theoretical') values of 33.6 and $34.2 \mathrm{kcal} \mathrm{mol}^{-1}$ for $\left[\mathrm{C}_{7} \mathrm{H}_{8}\right]^{+\cdot}$ from toluene (obtained on the basis of two different mechanisms). ${ }^{10 c}$ The present results suggest that the true value should be closer to the lower limit than to the upper one estimated above, strongly supporting the calculated height ${ }^{10 c}$ of the isomerization barrier.

Contrary to this, the estimated energy barrier for ring contraction of cycloheptatriene-type radical cations $\left(20<E_{\text {isom }}^{\neq}<36 \mathrm{kcal} \mathrm{mol}^{-1}\right)$ cannot be compared reliably with the corresponding theoretical values ( 39.2 and $39.8 \mathrm{kcal} \mathrm{mol}^{-110 \mathrm{c}}$ ), since, as pointed out by 


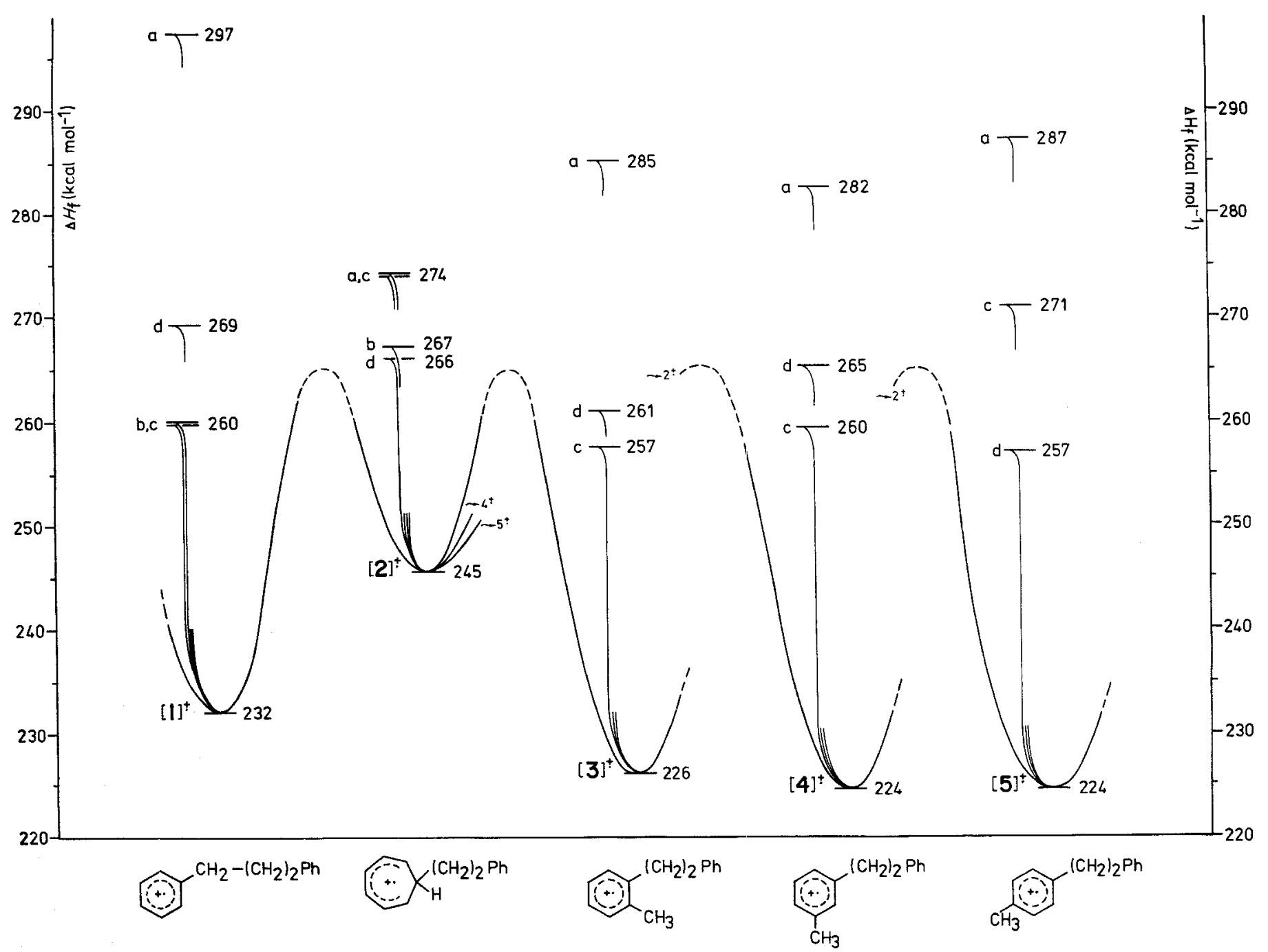

Figure 4. Simplified energy profile for the skeletal $\left[\mathrm{C}_{7} \mathrm{H}_{8}\right]^{+-}-$type isomerization of the molecular ions [1 $]^{+\cdot}-[5]^{+\cdot}$ and their fragmentation to (a) $\left[\mathrm{C}_{7} \mathrm{H}_{7}\right]^{+}+\mathrm{C}_{8} \mathrm{H}_{9}$, (b) $\left[\mathrm{C}_{7} \mathrm{H}_{8}\right]^{+*}+\mathrm{C}_{8} \mathrm{H}_{8}$, (c) $\left[\mathrm{C}_{8} \mathrm{H}_{8}\right]^{++}+\mathrm{C}_{7} \mathrm{H}_{8}$ and (d) $\left[\mathrm{C}_{8} \mathrm{H}_{9}\right]^{+}+\mathrm{C}_{7} \mathrm{H}_{7}$. The dashed tops represent lower limits to the isomerization barriers.

the authors, ${ }^{10 c}$ the vertical ionization energy of cycloheptatriene (and its derivatives) depends unusually strongly on the geometry of the ground state neutral molecules. On the other hand, the isomerization barrier estimated for the radical cations of dialkylbenzenes $\left(40<E_{\text {isom }}^{z}<53 \mathrm{kcal} \mathrm{mol}^{-1}\right)$-which has not been calculated yet - should be similarly reliable as has been found in the case of monoalkylbenzenes. Indeed, it seems reasonable to assume that an additional alkyl group at the ionized aromatic nucleus increases the isomerization barrier simply by decreasing the ionization energy of the parent molecules, whereas the thresholds for (skeletal) isomerization and for fragmentation should both be influenced to a much smaller extent (cf. Fig. 4).

Substituents other than alkyl may influence more effectively the height of the $\left[\mathrm{C}_{7} \mathrm{H}_{8}\right]^{++}$type isomerization barrier. Thus, strongly electron donating $-E$ substituents ${ }^{30}$ as e.g. $\mathrm{OCH}_{3}$ seem to stabilize ${ }^{31}$ the initially formed (radical) cation towards isomerization whereas electron withdrawing $+E$ substituents ${ }^{30}$ as e.g. $\mathrm{CN}^{32}$ and $\mathrm{NO}_{2}{ }^{10 \mathrm{~d}}$ possibly decrease slightly the isomerization barrier.

\section{EXPERIMENTAL}

\section{Mass spectrometric measurements}

The mass spectra (Table 2) were measured with a Varian MAT 311 A double focusing instrument $(\pi$ magnetic sector followed by $\pi / 2$ electric sector) and represent the average of two sets of at least four scans taken on two different days. Operating conditions: electron energy $70 \mathrm{eV}$, emission current $2 \mathrm{~mA}$, accelerating voltage $3 \mathrm{kV}$, source temperature $c .250^{\circ} \mathrm{C}$. Samples were introduced via a water-cooled direct inlet system using an aluminium crucible closed by a cap with a very small hole. The crucible was heated slightly in order to achieve a nominal source pressure of $\$ 3 \times 10^{-6}$ Torr.

Compounds 1 and 1a were remeasured in this manner and showed no significant deviations from the previous results. ${ }^{11}$ The $70 \mathrm{eV}$ mass spectra of the cht isomers 2 and $2 \mathrm{a}$ were found to be temperature dependent; without heating the ion source, $\mathbf{2 a}$ showed a drastic increase of the peak at $\mathrm{m} / \mathrm{z} 91$ and a corresponding decrease at $m / z 96$ and $m / z$ 97. The effect of 
Table 6. Skeletal isomerixation and apparent activation energies" for fragmentation of the molecular cations of toluene, cycloheptatriene and some derivatives

\begin{tabular}{|c|c|c|c|}
\hline Compound & Fragmentation reaction & $\mathrm{A}[\mathrm{F}]^{+}-l(\mathrm{M})$ & $\begin{array}{l}\text { Skeletal isomerization } \\
\text { observed }\end{array}$ \\
\hline $\begin{array}{l}\text { Toluene } \\
\text { Ethylbenzene } \\
\text { n-Propylbenzene } \\
\text { Diphenylmethane } \\
\text { 1,2-Diphenylethane } \\
\text { Benzyl phenyl ether } \\
\text { Cycloheptatriene } \\
\text { 7-Methylcycloheptatriene } \\
\text { 7-(n-Butyl)cycloheptatriene } \\
\text { o-Xylene } \\
\text { m-Xylene } \\
\text { p-Xylene } \\
\text { 1-Ethyl-4-methylbenzene }\end{array}$ & $\begin{array}{l}{[\mathrm{M}]^{+\cdot} \rightarrow\left[\mathrm{C}_{7} \mathrm{H}_{7}\right]^{+}+\mathrm{H}^{\cdot}} \\
{[\mathrm{M}]^{+\cdot} \rightarrow\left[\mathrm{C}_{7} \mathrm{H}_{7}\right]^{++}+\mathrm{CH}_{3}} \\
{[\mathrm{M}]^{+\cdot} \rightarrow\left[\mathrm{C}_{8} \mathrm{H}_{9}\right]^{+}+\mathrm{H}^{\cdot}} \\
{[\mathrm{M}]^{+\cdot} \rightarrow\left[\mathrm{C}_{7} \mathrm{H}_{7}\right]^{+}+\mathrm{C}_{2} \mathrm{H}_{5} \cdot} \\
{[\mathrm{M}]^{+\cdot} \rightarrow\left[\mathrm{C}_{13} \mathrm{H}_{11}\right]^{+}+\mathrm{H}^{+}} \\
{[\mathrm{M}]^{+\cdot} \rightarrow\left[\mathrm{C}_{7} \mathrm{H}_{7}\right]^{+}+\mathrm{C}_{7} \mathrm{H}_{7}} \\
{[\mathrm{M}]^{+\cdot} \rightarrow\left[\mathrm{C}_{7} \mathrm{H}_{7}\right]^{+}+\mathrm{C}_{6} \mathrm{H}_{5} \mathrm{O}^{\circ}} \\
{[\mathrm{M}]^{+\cdot} \rightarrow\left[\mathrm{C}_{7} \mathrm{H}_{7}\right]^{+}+\mathrm{H}^{+}} \\
{[\mathrm{M}]^{+\cdot} \rightarrow\left[\mathrm{C}_{7} \mathrm{H}_{7}\right]^{+}+\mathrm{CH}_{3}} \\
{[\mathrm{M}]^{+\cdot} \rightarrow\left[\mathrm{C}_{7} \mathrm{H}_{7}\right]^{+}+\mathrm{C}_{4} \mathrm{H}_{9}} \\
{[\mathrm{M}]^{+\cdot} \rightarrow\left[\mathrm{C}_{7} \mathrm{H}_{7}\right]^{+}+\mathrm{CH}_{3}} \\
{[\mathrm{M}]^{+\cdot} \rightarrow\left[\mathrm{C}_{7} \mathrm{H}_{7}\right]^{+}+\mathrm{CH}_{3}} \\
{[\mathrm{M}]^{+\cdot} \rightarrow\left[\mathrm{C}_{7} \mathrm{H}_{7}\right]^{+}+\mathrm{CH}_{3}} \\
{[\mathrm{M}]^{+\cdot} \rightarrow\left[\mathrm{C}_{8} \mathrm{H}_{9}\right]^{+}+\mathrm{CH}_{3}}\end{array}$ & $\begin{array}{l}63-67^{7 b}, 48-49^{29 a} \\
56^{7 a}, 49^{7 b, 34},<48^{29 b} \\
61^{7 b}, \\
67^{7 b}, 49^{34},<45^{29 b} \\
58^{36} \\
44^{27 c} \\
30^{33}, 25^{b} \\
36^{7 a}-39^{7 b} \\
37^{7,37} \\
-7 \\
60^{7 b},<53^{29 b} \\
62^{34,7 b},<53^{29 b} \\
60^{7 b},<53^{29 b} \\
64^{c}\end{array}$ & 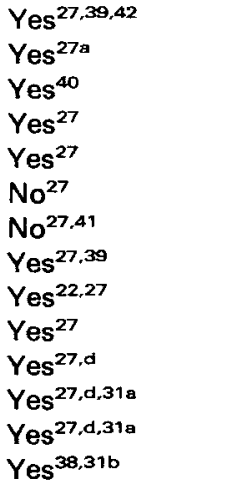 \\
\hline
\end{tabular}

a in kcal mol ${ }^{-3}$. ${ }^{b}$ Value determined in our laboratories. ${ }^{c}$ Using $A\left[C_{8} H_{g}\right]^{+}$from Ref. 38 and $I(p-X y l e n e) .^{7 b}$

${ }^{d}$ Skeletal isomerization precedes aiso loss of $\mathrm{H}^{-40}$ which exhibits very similar energy requirements. ${ }^{7 b}$

temperature on the relative abundances of the ' $\mathrm{C}_{8}$ ' ions was not investigated. As already noted for 1 and its labelled analogues, ${ }^{11 b}$ the mass spectra of $\mathbf{2}$ and $\mathbf{2 a}$ are markedly sensitive to focusing conditions of the ion source. Therefore, all spectra which are compared with each other in the present paper were recorded at approximately constant focusing potentials, yielding a reproducibility of $c . \pm 5 \%$.

The fragmentation of the metastable molecular ions within the 1st FFR region (Table 3) was measured on the same instrument at fixed magnetic and electric sector fields by increasing the accelerating voltage $\left(U_{0}=1 \mathrm{kV}\right)$ keeping all other conditions unchanged. The fragmentation of the metastable molecular ions in the 2nd FFR (Table 4) was measured with the same instrument by decreasing the electric sector voltage $\left(U_{0}=510 \mathrm{~V}\right)$ at fixed accelerating voltage $(3 \mathrm{kV})$ and fixed magnetic field. The width of the intermediate focus slit was $0.2 \mathrm{~mm}$. The release of kinetic energy was determined for the metastable ions decomposing in the 2 nd FFR. Correction was made for the width of the stable ion beam by taking the square root of the difference between the squares of the widths of the diffuse and the (mass-reduced) normal peak.

Ionization and appearance energies (Table 5) were measured semi-automatically with a Vacuum Generators MM 12B single focusing instrument at an emission current of $20 \mathrm{~mA}$. The samples were introduced via the high temperature inlet system $\left(150^{\circ} \mathrm{C}\right)$ to give a nominal source pressure of $<1.0 \times 10^{-6}$ Torr at a source temperature of c. $200^{\circ} \mathrm{C}$. The data were obtained from three to five independent runs for each compound and were evaluated using the semi-log plot method of Lossing, Tickner and Bryce. ${ }^{23 b}$ Although the ionization efficiency curves of the fragment ions were not parallel to those of the corresponding molecular ion and of the standard, the error might not be too serious as a control evaluation of $A\left[\mathrm{C}_{8} \mathrm{H}_{9}\right]^{+}$ from 2 using Warren's extrapolated voltage difference method $^{23 b}$ showed no significant deviation.

\section{Preparation of compounds}

The preparation of $\mathbf{1}$ and $\mathbf{1 a}$ has been described previously. ${ }^{11}$ The deuterium contents of $1 \mathbf{a}$ and the other deuterated isomers are given in Table 1.

1-(7-Cycloheptatrienyl)-2-phenylethane (2) and 1-(7cycloheptatrienyl)-2-[ $\left.d_{5}\right]$ phenylethane (2a) were prepared by slow addition of tropylium tetrafluoroborate to a solution of 2-phenylethylmagnesium bromide and $2-\left[d_{5}\right]$ phenylethylmagnesium bromide in ether, respectively, following essentially a procedure given by Kessler. ${ }^{43}$ 2-Phenylethylmagnesiumbromide was prepared from $\left[d_{5}\right]$ phenylmagnesiumbromide and oxirane (similarly to Ramsden et al. $^{44}$ ) followed by treatment of the resulting alcohol with $\mathrm{PBr}_{3}$ in $\mathrm{CCl}_{4}$ according to Bergs. ${ }^{45}$ Working on a small scale (max. c. $60 \mathrm{mmol}$ Grignard reagent) some 1,4-diphenylbutane $\left(\left[d_{0}\right]\right.$ and $\left[d_{10}\right]$, respectively) is produced as a co-product. This contamination can be reduced to $<5 \%$ (from ${ }^{1} \mathrm{H}$ NMR) after distillation (b.p.0.05-0.1 $89-100^{\circ} \mathrm{C}$ ) and fractional distillation (b.p.0.05-0.1 $87-88^{\circ} \mathrm{C}$, yield $37-$ $41 \%$ ), followed by fractionated crystallization of the corresponding 1,4-diphenylbutane. The ${ }^{1} \mathrm{H}$ NMR spectra $\left(\mathrm{CDCl}_{3}\right)$ of both 2 and $2 \mathrm{a}$ were consistent with the exclusive formation of 7-aralkyl substituted cycloheptatrienes (cf. Refs. 19 and 46$) ; \tau \approx 8.0\left(\mathrm{~m}, 1-\mathrm{CH}_{2}\right.$ and $\left.\mathrm{H}^{7}\right), \quad 7.2\left(\mathrm{t}, 2-\mathrm{CH}_{2}\right), 4.8\left(\mathrm{dd}, \mathrm{H}^{1} / \mathrm{H}^{6}\right), \quad 3.9$ $\left(\mathrm{m}, \mathrm{H}^{2} / \mathrm{H}^{5}\right)$ and $3.4\left(\mathrm{~m}, \mathrm{H}^{3} / \mathrm{H}^{4}\right)$, relative intensities of the latter signals $0.9: 1.0: 0.9$. The samples were not purified further (by preparative GLC) in order to prevent thermal isomerization. ${ }^{19}$ However, reliable corrections of the $70 \mathrm{eV}$ mass spectra (Table 2) have been made by subtracting the known ${ }^{47}$ mass spectra of the corresponding 1,4-diphenylbutanes.

The 1-phenyl-2-tolylethanes 3-5 were synthesized by a Wittig reaction of the corresponding tolualdehyde and benzyl triphenyl phosphonium bromide in ethanol to give the appropriate stilbene derivative which was hydrogenated by diimide reduction. ${ }^{48}$ The synthesis of the unknown deuterated compounds 3a-5a was carried out as described for the para isomer (5a). According to a procedure given for the preparation of unlabelled benzyl bromide, ${ }^{49}$ paraformaldehyde $(4.75 \mathrm{~g}$, $52.8 \mathrm{mmol}$ ) and finely powdered dry $\mathrm{NaBr}(19.6 \mathrm{~g}$, $190 \mathrm{mmol}$ ) were suspended in a mixture of $\left[d_{6}\right]$ benzene $(9.5 \mathrm{~g}, 113 \mathrm{mmol})($ Merck) and glacial acetic acid 
$(8.8 \mathrm{ml})$. The mixture was stirred vigorously and refluxed while a mixture of $\mathrm{H}_{2} \mathrm{SO}_{4}(27.8 \mathrm{~g}, 96 \%)$ and glacial acetic acid $(14.1 \mathrm{ml})$ was added over a period of $4 \mathrm{~h}$. The mixture was refluxed for another $14 \mathrm{~h}$ with stirring. After cooling water was added, the resulting oil was separated, and the water phase was extracted with benzene. The combined organic fractions were washed with water, $5 \%$ sodium carbonate, again with water and dried over magnesium sulfate. After evaporation of the benzene, the distillation afforded $14.5 \mathrm{~g}$ (73\%) [ $d_{s}$ ]phenylmethyl bromide, b.p. ${ }_{12} 86^{\circ} \mathrm{C}, \mathrm{D}$ content $94.1 \% d_{5}, 5.4 \% d_{4}, 0.5 \% d_{3}$ as shown by mass spectrometry.

The labelled $\left[d_{5}\right]$ benzyl bromide was converted to ([ $d_{s}$ Iphenylmethyl)triphenylphosphonium bromide by reacting the labelled bromide $(8.4 \mathrm{~g}, 48 \mathrm{mmol})$ with

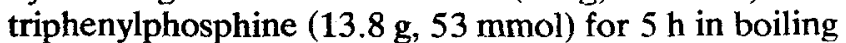
toluene $(50 \mathrm{ml}) .^{50}$ The resulting salt was used directly after washing with hot benzene (yield $94 \%$ ).

According to a procedure given for styrylpyridines, ${ }^{51}$ the labelled phosphonium salt $(6.85 \mathrm{~g}$, $15.6 \mathrm{mmol}$ ) was dissolved in a freshly prepared solution of sodium ethoxide from sodium metal $(0.30 \mathrm{~g}$, 13 mmol) in dried ethanol under $\mathrm{N}_{2}$ atmosphere. 4Methylbenzaldehyde $(1.43 \mathrm{~g}, 11.9 \mathrm{mmol})$ (or a corresponding isomer) was added with vigorous stirring. Stirring was continued for $50 \mathrm{~h}$, and the mixture was poured on ice/water and extracted with ether. After filtration of some precipitated phosphine oxide the combined extracts were washed with aqueous bisulfite and water and dried over anhydrous magnesium sulfate. The ether was removed and the residue recrystallized twice from ethanol yielding $1.85 \mathrm{~g}(78 \%)$ of 1 -(4methylphenyl)-2-[ $\left.d_{5}\right]$ phenylethene (m.p. $117-118^{\circ} \mathrm{C}$ ). 1-(2-methylphenyl)-2-[ $\left.d_{5}\right]$ phenylethene and 1-(3methylphenyl)-2-[ $\left.\boldsymbol{d}_{\mathbf{5}}\right]$ phenylethene were obtained in similar ways in yields of $75 \%$ and $69 \%$, respectively.

1-(4-Methylphenyl)-2- $\left[d_{5}\right]$ phenylethane $(0.39 \mathrm{~g})$ $2.0 \mathrm{mmol}$ ) were dissolved together with $\mathrm{CuSO}_{4} \cdot 5 \mathrm{H}_{2} \mathrm{O}$ $(10 \mathrm{mg})$ in a mixture of 2-propanol $(25 \mathrm{ml})$ and $85 \%$ hydrazine hydrate $(2 \mathrm{ml})$. Air was bubbled through this mixture overnight. Working up with water and ether afforded 1-(4-methylphenyl)-2-[d $\left.\boldsymbol{d}_{5}\right]$ pheny]ethane (5a) in quantitative yield (m.p. $28-29^{\circ} \mathrm{C}$ after recrystallization from ethanol). In the case of 1-(2methylphenyl)-2-[ $\left.d_{5}\right]$ henylethane $(3 a)$ and 1 (3-methylphenyl)-2-[ $\left.d_{5}\right]$ phenylethane (4a), further hydrazine hydrate and $\mathrm{CuSO}_{4} .5 \quad \mathrm{H}_{2} \mathrm{O}$ were added several times during the hydrogenation. $3 \mathbf{a}$ and $\mathbf{4 a}$ were purified by micro-distillation (b.p.0.6 $132^{\circ} \mathrm{C}$ and b.p.o.5 $124^{\circ} \mathrm{C}$ ).

Deuterium contents of $3 \mathbf{a}, 4 \mathbf{a}$ and $5 \mathbf{a}$ (Table 1) did not differ significantly from that of the $\left[d_{5}\right]$ benzyl bromide (vide supra); hence loss of the label did not occur in both the Wittig reaction and the diimide reduction.

\section{Ackmowledgement}

This work was supported by the 'Forschungsprojekt 2163 der Universität Bielefeld' and by the 'Fonds der Chemischen Industrie'.

\section{REFERENCES}

1. H. M. Grubb and S. Meyerson, in Mass Spectrometry of Organic lons, ed. by F. W. McLafferty, Chapt. 10 Academic Press, New York (1963).

2. H. Budzikiewicz, C. Djerassi and D. H. Williams, Mass Spectrometry of Organic Compounds, p. 76ff. Holden-Day, San Francisco (1967).

3. J. T. Bursey, M. M. Bursey and D. G. I. Kingston, Chem. Rev. 73, 191 (1973).

4. A. L. Burlingame, R. E. Cox and P. J. Derrick, Anal. Chem. 46, 248R (1974).

5. Mass Spectrometry, Specialist Periodical Reports, Vols. 1-4. The Chemical Society, London $(1971,1973,1975$ and 1977): (a) l. Howe in Vol. 1, Chapt. 2, pp. 49-50, 57-58 63-68, 71-72, and J. H. Bowie in Vol. 1, Chapt. 3, pp. 97-99, 134 (ed. by D. H. Williams); (b) l. Howe in Vol. 2, Chapt. 2 , pp. 40, 56, 66-68, 72-73, and J. H. Bowie in Vol. 2, Chapt. 3 , pp. 94-97, 135 (ed. by D. H. Williams); (c) T. W. Bentley in Vol. 3, Chapt. 2, pp. 65, 70-71 (ed. by R. A. W. Johnstone) (d) T. W. Bentley in Vol. 4, Chapt. 2, p. 38 (ed. by R. A. W. Johnstone).

6. M. A. Baldwin, F. W. McLafferty and D. M. Jerina, J. Am. Chem. Soc. 97, 6169 (1975).

7. (a) J. L. Franklin, J. G. Dillard, H. M. Rosenstock, J. T. Herron, K. Draxl and F. H. Field, Ionization Potentials, Appearance Potentials and Heats of Formation of Gaseous Positive lons, US Department of Commerce, NSRDS-NBS 26, Washington, DC (1969); (b) H. M. Rosenstock, K. Draxl, B. W. Steiner and J. T. Herron, J. Phys. Chem. Ref. Data 6, Suppl. No. 1 (1977).

8. (a) G. Hvistendahl and D. H. Williams, J. Am. Chem. Soc. 97, 3097 (1975); (b) G. Hvistendahl, R. D. Bowen and D. H. Williams, Chem. Commun. 924 (1976): (c) R. D. Bowen, J. H. Kalman and D. H. Williams, J. Am. Chem. Soc. 99, 5481 (1977); (d) R. D. Bowen and D. H. Williams, J. Am. Chem. Soc. 99, 6822 (1977); (e) R. D. Bowen, D. H. Williams and G. Hvistendahl, J. Am. Chem. Soc. 99, 7509 (1977).

9. (a) W. J. Hehre and J. A. Pople, J. Am. Chem. Soc. 94, 6901
(1977); (b) L. Radom, J. A. Pople, V. Buss and P. V. R. Schleyer, J. Am. Chem. Soc. 94, 311 (1972).

10. (a) C. Cone, M. J. S. Dewar and D. Landman, J. Am. Chem. Soc. 99, 372 (1977); (b) M. J. S. Dewar, R. C. Haddon, A. Kormonicki and H. Szepa, J. Am. Chem. Soc. 99, 377 (1977); (c) M. J. S. Dewar and D. Landman, J. Am. Chem. Soc. 99, 2446 (1977); (d) M. J. S. Dewar and D. Landman, J. Am. Chem. Soc. 99, 4633 (1977).

11. (a) D. Kuck and H.-Fr. Grützmacher, Org. Mass Spectrom. 13, 81 (1978); (b) D. Kuck and H.-Fr. Grützmacher, Org. Mass Spectrom. 13, 90 (1978).

12. American Petroleum Institute Research Project 44, Spectrum No. 1967.

13. (a) H. Budzikiewicz, C. Djerassi and D. H. Williams, Mass Spectrometry of Organic Compounds, Chapt. 1. HoldenDay, San Francisco (1967); (b) J. H. Beynon, Mass Spectrometry and its Application to Organic Chemistry, Chapt. 9. Elsevier, Amsterdam (1960).

14. (a) H. M. Rosenstock, V. H. Dibeler and F. N. Harllee, J. Chem. Phys. 40, 591 (1964); (b) For an application of the inversion of this rule, see: D. H. Williams and R. D. Bowen, Org. Mass Spectrom. 11, 223 (1976).

15. J. H. Beynon, R. G. Cooks, K. R. Jennings and A. J. Ferrer-Correia, Int. J. Mass Spectrom. Ion Phys. 18, 87 (1975).

16. R. G. Cooks, J. H. Beynon, R. M. Caprioli and G. R. Lester, Metastable lons, Chapt. 4. Elsevier, Arnsterdam (1973).

17. (a) S. Meyerson, I. Puskas and E. K. Fields, J. Am. Chem. Soc. 95, 6056 (1973); (b) M. A. Winnik, D. Saunders, G. Jackowski and R. E. Trueman, J. Am. Chem. Soc. 96, 7510 (1974).

18. (a) P. J. Derrick and A. L. Burlingame, J. Am. Chem. Soc. 96, 4909 (1974); (b) P. J. Derrick, A. M. Falick and A. L: Burlingame, J. Am. Chem. Soc. 94, 6794 (1972).

19. A. P. ter Borg and H. Kloosterziel, Recl. Trav. Chim. PaysBas, 88, 266 (1969) and preceding papers in that series. 
20. S. Meyerson and L. C. Leitch, J. Am. Chem. Soc. 93, 2244 (1971).

21. J. F. Wolf, R. H. Staley, I. Koppel, M. Taagepera, R. T. Mclver Jr, J. L. Beauchamps and R. W. Taft, J. Am. Chem. Soc. 99,5417 (1977).

22. A. Venema, N. M. M. Nibbering and Th. J. de Boer, Tetrahedron Lett. 2141 (1971).

23. (a) D. H. Williams and I. Howe, Principles of Organic Mass Spectrometry, Chapt. 5. McGraw-Hill, London (1972); (b) R. W. Kiser, Introduction to Mass Spectrometry and its Applications, Chapt. 8. Prentice-Hall, Englewood Cliffs (1965).

24. M. J. S. Dewar and D. Landman, J. Am. Chem. Soc. 99, 7439 (1977).

25. (a) J. L. Franklin, J. G. Dillard, H. M. Rosenstock, J. T. Herron, K. Draxl and F. H. Field, Ionization Potentials, Appearance Potentials and Heats of Formation of Gaseous Positive lons, p. 1-162. US Department of Commerce, NSRDS-NBS 26, Washington, DC (1969).

26. A. N. H. Yeo and D. H. Williams, Chem. Commun. 886 (1970).

27. (a) F. W. McLafferty and J. Winkler, J. Am. Chem. Soc. 96. 5182 (1974); (b) J. Winkler and F. W. McLafferty, J. Am. Chem. Soc. 95, 7533 (1973); (c) F. W. McLafferty, T. Wachs, C. Lifshitz, G. Innorta and P. Irving, J. Am. Chem. Soc. 92, 6867 (1970).

28. (a) I. Howe, N. Uccella and D. H. Williams, J. Chem. Soc. Perkin Trans. 2, 76 (1973); (b) C. Köppel and F. W. McLafferty, Chem. Commun. 810 (1976).

29. (a) R. C. Dunbar, J. Am. Chem. Soc. 95, 472 (1973); (b) R. C. Dunbar, J. Am. Chem. Soc. 95, 6191 (1973).

30. M. J. S. Dewar and R. C. Dougherty, The PMO Theory of Organic Chemistry, Plenum Press, New York (1975)

31. (a) P. Brown, Org. Mass Spectrom. 2, 1085 (1969); (b) P. Brown, Org. Mass Spectrom. 2, 1317 (1969).

32. J. van der Greef, T. A. Molenaar-Langeveld and N. M. M. Nibbering, Int. J. Mass Spectrom. Ion Phys. submitted for publication. (We are indebted to these authors for sending us their manuscript prior to publication.)

33. R. S. Ward, R. G. Cooks and D. H. Williams, J. Arn. Chem. Soc. 91, 2727 (1969).

34. M. E. Akopyan and F. I. Vilesov, Zh. Fiz. Khim. 40, 125 (1966) (Russ. J. Phys. Chem. 40, 63 (1966))

35. D. Kuck, Diploma Thesis, Hamburg (1972).

36. F. Bohlmann, C. Köppel, B. Müller, H. Schwarz and P. Weyerstahl, Tetrahedron 30, 1011 (1974).

37. F. Meyer, P. Haynes, S. McLean and A.' G. Harrison, Can. J. Chem. 43, 211 (1965)
38. F. Meyer and A. G. Harrison, J. Am. Chem. Soc. 86, 4757 (1964).

39. (a) I. Howe and F. W. McLafferty, J. Am. Chem. Soc. 93, 99 (1971); (b) K. Levsen, F. W. McLafferty and D. M. Jerina, J. Am. Chem. Soc. 95, 6332 (1973).

40. C. Köppel, C. C. Van de Sande, N. M. M. Nibbering, T. Nishishita and F. W. McLafferty, J. Am. Chem. Soc. 99. 2883 (1977).

41. P. Brown, J. Am. Chem. Soc. 90, 2694 (1968).

42. J.-A. A. Jackson, S. G. Lias and P. Ausloos, J. Am. Chem. Soc. 99, 7515 (1977).

43. H. Keßler, in Houben-Weyl, Methoden der Organischen Chemie, ed. by E. Müller, Vol. 5/1d, p. 326. Thieme, Stuttgart (1972).

44. H. E. Ramsden, A. E. Balint, W. R. Whitford, J. J. Walburn and R. Cserr, J. Org. Chem. 22, 1202 (1957).

45. H. Bergs, Ber. 67, 244 (1934).

46. A. P. ter Borg. H. Kloosterziel and N. van Meurs, Recl. Trav. Chim. Pays Bas 82, 717 (1963).

47. D. Kuck and H.-Fr. Grützmacher, in preparation

48. (a) E. J. Corey, W. L. Mock and D. J. Pasto, Tetrahedron Lett. 347 (1961); (b) S. Hünig, H.-R. Müller and W. Thier, Tetrahedron Lett. 353 (1961).

49. G. Kubiczek and L. Neugebauer, Monatsh. Chem. 81, 917 (1950).

50. Organikum, 13th Edn, p. 232. VEB Deutscher Verlag der Wissenschaften, Berlin (1974).

51. J. L. R. Williams, R. E. Adel, J. M. Carlson, G. A. Reynolds, D. G. Borden and J. A. Ford Jr, J. Org. Chem. 28, 387 (1963).

52. F. P. Lossing, Can. J. Chem. 49, 357 (1971).

53. J. Occolowitz, cited in Ref. $39 \mathrm{~b}$ as a private communication.

54. H.-Fr. Grützmacher and M. Puschmann, Chem. Ber. 104, 2079 (1971).

55. H. Wincel and Z. Kecki, Nukleonika 8, 215 (1963)

56. G. J. Gleicher, D. D. Newkirk and J. C. Arnold, J. Am. Chem. Soc. 95, 2526 (1973).

57. H.-Fr. Grützmacher, Org. Mass Spectrom. 3, 131 (1970).

58. J. A. Kerr, Chem. Rev. 66, 465 (1966).

59. (a) A. G. Harrison, L. R. Honnen, H. J. Dauben Jr and F. P. Lossing, J. Am. Chem. Soc. 82, 5593 (1960); (b) G. Vincow. H. J. Dauben Jr, F. R. Hunter and W. V. Volland, J. Am. Chem. Soc. 91, 2823 (1969).

Received 28 July 1978; accepted (revised) 19 September 1978 (C) Heyden \& Son Ltd, 1979

\section{APPENDIX}

The heats of formation of the neutral isomers $(M)$ are calculated by the method of thermochemical increments, ${ }^{7 \mathrm{a}}$ starting from $\Delta H_{\mathrm{f}}(\mathrm{M})$ for the corresponding $\mathrm{C}_{8} \mathrm{H}_{10}$ hydrocarbons. Thus, $\Delta H_{\mathrm{f}}(\mathbf{1})=$ $29.3 \mathrm{kcal} \mathrm{mol}^{-1}, 11 \mathrm{a} \quad \Delta H_{\mathrm{f}}(\mathbf{2})=59.5 \mathrm{kcal} \mathrm{mol}^{-1}, \quad \Delta H_{\mathrm{f}}(\mathbf{3})=26.8 \mathrm{kcal}$ $\mathrm{mol}^{-1}, \quad \Delta H_{f}(4)=26.4 \mathrm{kcal} \mathrm{mol}^{-1}$ and $\Delta H_{f}(5)=26.6 \mathrm{kcal} \mathrm{mol}^{-1}$.

\section{Figure 2(a)}

$\Delta H_{f}\left(\left[c-\mathrm{C}_{6} \mathrm{H}_{5} \mathrm{CH}_{2}\right]^{+}\right)=213 \mathrm{kcal} \mathrm{mol}^{-1} 7 \mathrm{~b}, 52$ and $\Delta H_{f}\left(\left[c-\mathrm{C}_{7} \mathrm{H}_{7}\right]^{+}\right)=$ $214 \mathrm{kcal} \mathrm{mol}^{-1} 7 \mathrm{~b}$ (cf. also Refs. 7a and 42). The value given for $\Delta H_{\mathrm{f}}(m-\mathrm{xylyl})=\Delta H_{\mathrm{f}}(p$-xylyl) in Ref. $7 \mathrm{a}$ is certainly too low. Assuming no additional effect of the $\mathrm{CH}_{3}$ substituent, $\Delta H_{\mathrm{f}}(\mathrm{xylyl})$ is estimated for all isomers in analogy to $\Delta H_{\mathrm{f}}$ (benzyl) (vide infra) from $\Delta H_{\mathrm{f}}($ xylenes $)+\mathrm{D}\left(\mathrm{C}_{6} \mathrm{H}_{5} \mathrm{CH}_{2}-\mathrm{H}\right)-\Delta H_{\mathrm{f}}\left(\mathrm{H}^{*}\right)$

$$
=(\approx 4)^{7}+85^{58}-52.1^{7}=37 \mathrm{kcal} \mathrm{mol}^{-1}
$$

$\Delta H_{\mathrm{f}}(\beta$-phenylethyl $)=54.2 \mathrm{kcal} \mathrm{mol}^{-1}$

estimated on the basis of $\Delta H_{\mathrm{f}}\left(n-\mathrm{C}_{3} \mathrm{H}_{7}\right)=22.1 \mathrm{kcal} \mathrm{mol}^{-17 \mathrm{a}}$ $\left(20.7 \mathrm{kcal} \mathrm{mol}^{-1} \mathrm{7b}^{7 \mathrm{~b}}\right)$ using appropriate increments. ${ }^{7 \mathrm{a}} \Delta H_{\mathrm{f}}(7$-methylcycloheptatrien-7-y1) $\approx 63 \mathrm{kcal} \mathrm{mol}^{-1}$ has been calculated from $\Delta \mathrm{H}_{\mathrm{f}}\left(7-\mathrm{CH}_{3}-\left(c-\mathrm{C}_{7} \mathrm{H}_{7}\right)\right)=37.2 \mathrm{kcal} \mathrm{mol}{ }^{-1},{ }^{7 \mathbf{a}} \quad \mathrm{D}\left(\mathrm{C}^{7}-\mathrm{H}\right) \approx 78 \mathrm{kcal}$ $\mathrm{mol}^{-1}$ (estimated value, cf Ref. 25, making allowance for a stabilizing effect of the $\mathrm{CH}_{3}$ group on $\mathrm{C}^{7}$ ) and $\Delta H_{\mathrm{f}}\left(\mathrm{H}^{\circ}\right)=$ $52.1 \mathrm{kcal} \mathrm{mol}^{-1} .{ }^{7 \mathrm{a}}$

\section{Figure 2(b)}

$\Delta H_{f}\left([5 \text {-methylenecyclohexa-1.3-diene }]^{+\cdot}\right)=215 \mathrm{kcal} \mathrm{mol}^{-1} 11 \mathrm{la} \quad$ (cf. also Refs. $10 \mathrm{c}$ and 53$)$; this value is very similar to $\Delta H_{f}$ ([toluene $\left.]^{+-}\right) .^{7,10 c} \Delta H_{\mathrm{f}}\left(\left[\mathrm{c}-\mathrm{C}_{7} \mathrm{H}_{8}\right]^{+-}\right)=235 \mathrm{kcal} \mathrm{mol}^{-17 \mathrm{~b}}$ (cf. also Refs. $7 \mathrm{a}$ and $10 \mathrm{c}) . \quad \Delta H_{\mathrm{f}}$ (styrene $)=37 \mathrm{kcal} \mathrm{mol}^{-17 \mathrm{a}} \quad\left(35.2 \mathrm{kcal} \mathrm{mol}^{-1}{ }^{7 \mathrm{~b}}\right)$. $\Delta H_{\mathrm{f}}$ (heptafulvene) $=50 \mathrm{kcal} \mathrm{mol}^{-1} ;^{54}$ this value possibly represents a lower limit.

\section{Figure 3(a)}

$\Delta H_{\mathrm{f}}\left([\text { styrene }]^{+*}\right)=230 \mathrm{kcal} \mathrm{mol}^{-1} .^{7 b}$ The heats of formation of ionized $m$ - and $p$-xylylenes (quinodimethanes) are uncertain. According to an estimation, $\Delta H_{f}\left([o \text {-xylylene }]^{+\cdot}\right)=240 \mathrm{kcal} \mathrm{mol}^{-1} ; 55$ according to the relative stabilities of the neutral hydrocarbons, ${ }^{56}$ the meta and para isomers might exhibit slightly lower and higher heats of formation, respectively. $\Delta H_{f}\left([\text { heptafulvene }]^{+\cdot}\right) \leq-$ $250 \pm 10 \mathrm{kcal} \mathrm{mol}^{-1} .^{54}$ Following the argument of PMO theory, ${ }^{30}$ this value should represent an upper limit. $\Delta H_{f}$ (toluene $)=$ $11.95 \mathrm{kcal} \mathrm{mol}^{-1}, 7 \Delta H_{f}$ (cycloheptatriene) $=43.47 \mathrm{kcal} \mathrm{mol}^{-1}$ ? $^{7}$

\section{Figure 3(b)}

$\Delta H_{\mathrm{f}}\left(\left[\mathrm{CH}_{3}-\left(c-\mathrm{C}_{7} \mathrm{H}_{7}\right)\right]^{+}\right) \leqslant 208 \mathrm{kcal} \mathrm{mol}^{-1}$ has been estimated by suggesting a decrease by c. $6 \mathrm{kcal} \mathrm{mol}^{-1}$ of $\Delta \mathrm{H}_{\mathrm{f}}\left(\left[c-\mathrm{C}_{7} \mathrm{H}_{7}\right]^{+}\right)=$ $214 \mathrm{kcal} \mathrm{mol}^{-17 \mathrm{~b}}$ due to a methyl substituent. Not surprisingly, this value is much lower than the experimental one ${ }^{37}\left(239 \mathrm{kcal} \mathrm{mol}^{-1}\right.$, cf. Ref. 7a), but still considerably higher than that calculated recently $\left(190 \mathrm{kcal} \mathrm{mol}^{-1}\right) \cdot{ }^{24}$ The values used for $\Delta H_{f^{-}}$ $\left(\left[\mathrm{CH}_{3} \mathrm{C}_{6} \mathrm{H}_{4} \mathrm{CH}_{2}\right]^{+}\right)$are 213,214 and $222 \mathrm{kcal} \mathrm{mol}^{-1},{ }^{7 \mathrm{~b}}$ respectively, for the ortho, para and meta isomers. The latter value might be too high (cf. Refs. 7a and 24). $\Delta H_{f}\left([\text { ethylenebenzenium }]^{+}\right)=-$ $215 \mathrm{kcal} \mathrm{mol}^{-1} .^{57} \Delta H_{\mathrm{f}}$ (benzyl) $=45 \mathrm{kcal} \mathrm{mol}^{-158}$ (cf. also Ref. 7a). $\Delta H_{\mathrm{f}}($ cycloheptatriene-7-yl $)=65 \mathrm{kcal} \mathrm{mol}^{-1} 59$ or $71.2 \mathrm{kcal} \mathrm{mol}^{-1} .^{25}$ 